NBER WORKING PAPER SERIES

\author{
THE ROLE OF JUDGMENT AND \\ DISCRETION IN THE CONDUCT OF \\ MONETARY POLICY: CONSEQUENCES OF \\ CHANGING FINANCIAL MARKETS
}

Benjamin M. Friedman

Working Paper No. 4599

\author{
NATIONAL BUREAU OF ECONOMIC RESEARCH \\ 1050 Massachusetts Avenue \\ Cambridge, MA 02138 \\ December, 1993
}

This paper is part of NBER's research program in Monetary Economics. Any opinions expressed are those of the author and not those of the National Bureau of Economic Research. 


\title{
THE ROLE OF JUDGMENT AND DISCRETION IN THE CONDUCT OF MONETARY POLICY: CONSEQUENCES OF CHANGING FINANCIAL MARKETS
}

\begin{abstract}
Conventional monetary policy rules based on intermediate targets, like the growth of money or credit, rest on the presumption that relationships correcting these variables to key measures of nonfinancial economic activity like income and prices are robust. When financial markets change in such a way as to disrupt those relationships, rules based on intermediate targets no longer provide useful guides for conducting monetary policy. Under those circumstances, the central bank can instead exploit variables like money and credit as information variables. Doing so, however, inevitably requires case-by-case judgments. The greater is the impact of changing financial markets in this context, the stronger is the need for the central bank to exploit information both inclusively, in the sense of drawing on multiple and diversified sources of information rather than any one variable, and intensively, in the sense of allowing less time between policy decisions.
\end{abstract}

Benjamin M. Friedman

Harvard University

Littauer Center 127

Cambridge, MA 02138

and NBER 
Revised

November, 1993

THE ROLE OF JUDGMENT AND DISCRETION IN THE CONDUCT OF MONETARY ROLICY:

CONSEOUENCES OF CHANGING FINANCIAL MARKETS

\author{
Benjamin M. Friedman \\ Harvard University
}

There is no human affair which stands so constantly and so generally in close connection with chance as war. . Pity the poor warrior who is contented to crawl about in the beggardon of rules.

Karl von Clausewitz, On War

It may be true that war is the human activity most vitally subject to chance and happenstance, but monetary policy surely runs a close second. Making decisions and taking action in a setting driven by the unknown and the unknowable are a large part of what the making of monetary policy is all about. The central thesis of this paper is that Clausewitz's warning against the straight-jacket of predetermined rules in waging war is no less apt in the conduct of monetary policy

The more specific iocus of this paper's argument is the largely unanticipated, indeed unanticipatable, changes that have occurred in recent years - and that continue to occur and, in all likelihood, will keep on occurring - In the U.S. Einancial markets. Enumeration and description of particular changes in market structure or practice is not the point, however. Rather, the paper's object is to provide an overview, or more accurately a point of view or perhaps even a fhilosophy, in regard to the implications of such changes for the design of monetary policy. 
The central tenet of that point of view, or philosophy of the matter, is that such changes are, and for the foreseable future will be, ever-present and ongoing, to a sufficient extent as to vitiate any attempt to achieve a successful monetary policy by following a rule based on a pretedermined intermediate target. This view stands in specific contrast to the idea that a distinct set of market changes has occurred but has also now concluded, so that the financial and economic relationships most relevant to monetary policy will soon "settle down" to reflect some newly prevalling equilibrium. This paper's argument is that such an equilibrium may exist in some suitably fundamental sense, but not at the level of workaday detall and operational explicitness required to underpin a formal procedure, like that surrounding the use of an intermediate target, capable of appropriately governing monetary policy.

What too often seems forgotten in the endless debate over how to conduct monetary policy is that the question crucially at issue is not whether a sufficiently clever econometrician, surveying the wreckage after the fact, can devise some new specification, or invent some new variable, capable of restoring order to a collapsed relationship. What matters is whether it is possible to identify before the event a set of regularities of sufficient centrality and robustness to provide the qualitative and quantitative basis for sound policymaking. Even a careful reader of the voluminous literature of this subject might well infer that a positive answer to the former question somehow implied a favorable resolution of the latter. But the two issues are distinct, and it is the latter that must carry the weight of actual policymaking.

Section I provides the necessary context for what follows by briefly reviewing the motivation and logic underlying the use of information variables and intermediate targets in formulating and carrying out monetary policy. A novel feature of this discussion, compared to much of the usual literature of 
the subject, is the importance attached to the frequency in time over which a central bank revisits its choice of target, both qualitatively and quantitatively. When the time between such reconsiderations is lengthy, the use of any intermediate target becomes indistinguishable from a fixed (that is, no-feedback) rule. But when the time interval is short, what is formally the same procedure amounts in substance to a quite different approach based on an information variable. Section I also highlights the importance, under either an intermediate target procedure or an information variable procedure, of empirical links between the specific variable in question and nonfinancial economic activity.

Sections II and III turn to empirical evidence, documenting the collapse in recent years of some of the familiar relationships that, if they were sufficiently robust, could perhaps play a central role in guiding U.S. monetary policy. As a way of making more explicit the connection between these changes in empirical economic relationships and the changes that have taken place in the U.S. financial markets, Section III focuses on three "case study" examples: the narrow money stock (MI), which was at the center of the Federal Reserve System's most intensive effort to date to pursue monetary growth targets, during 1979.82: a broad credit aggregate, which my own work of a decade ago showed was comparable to most measures of money in its relationship to income; and the broad money stock (M2), which in recent years seems to have attracted more support as a target for U.S. monetary policy than any other such variable. With respect to $M 2$ in particular, this paper argues that today the Federal Reserve not only does not know the magnitude but does not even know the sign of the response of $M 2$ to open market operations. 
Finally. Section IV lakes up thr hard question of how to conduct monetary policy in an environment "so constantly and so generally in close connection" with chance and change. Even the tradicional injunction to do less when matters are uncertain, and in the limit do nothing at all when they are uncertain enough. has no meaning when basic relationships are so subject to change that it Is Impossible to say what "doing nothing" means in operational terms. Yet the Foleral Reserve must somehcw execute to the best of its ability its responstbilities, both statutory and moral, to further the common weal. The approach suggested here involves the use of information variables that arc Inclusive rather than exclusive - encompasing measures not only beyond the conventional monetary aggregates but. Indeed, beyond the confines of the banking, system or even the financial markets more generally - together with a frequency of decision making that for practical purposes renders even a single formal Intermediate target substantially equivalent to an information varlable. Section $V$ concludes by pointing to some valid and potentially important concerns, stemming from ongolng change in the U.S. financlal markets, that remain beyond the scope of the subject's treatment here. 


\section{Targets, Instruments and Information Varfables}

In principle, the Federal Open Market Committee could conclude each of its meetings by issuing a directive simply instructing the Committee's operating arm, the securities trading desk at the Federal Reserve Bank of New York, to do whatever is appropriate to make the U.S. economy grow at such-and-such percent per annum, or to limit price inflation to no more than such-and-such percent. The FOMC does not act in this way, presumably because the decisions thus taken would not be sufficiently operational. In other words, they would leave to the trading desk staff the entire matter of just what to do in order to achieve the specified growth rate, or the designated inflation.

One can, of course, imagine such a division of responsibility between staff and principals. But the Open Market Committee has never (to my knowledge) even come close to adopting that division, perhaps because the Federal Reserve System itself, as an institution, already stands in roughly this kind of relationship to the Congress. Moreover, economic growth and inflation are subject to many influences besides monetary policy, and many of those are surrounded with great uncertainty. Actual results may therefore differ from the corresponding intended outcomes despite even the best actions ex ante by monetary policy. Without at least some judgment about the plausible means to the designated ends, made either before the fact or after, how could the principals on the Committee ever determine whether their appointed staff had acted appropriately and competently?

At the other extreme, the Open Market Committee can also make decisions couched entirely in terms of quantities or prices that the trading desk's actions alone are sufficient to establish, either because desk actions are all that matters (as in the case of nonborrowed reserves) or in the sense that desk actions can readily be made dominant over other market forces, at least for a 
while (as in the case of the federal funds rate). The Committee has pursued approximately this kind of narrow focus on the instruments of monetary policy at various times in the past, and such an interpretation, with the funds rate as the designated instrument variable, seems not far off the mark as a description of the most recent period. Once the Committee itself makes what amounts to the choice of instrument -. meaning here not just the qualitative selection of which instrument to set but also the quantitative magnitude to be implemented .. responsibility for whether that choice is the right one clearly rests with the principals.

Both the Federal Reserve System and many of its critics, however, have long sought to frame the FOMC's decision making process in terms that are intermediate between these two extremes. One often stated reason is external: the desire, on the part of both the Congress and interested private citizens, to monitor the Federal Reserve's intentions and competence along just the lines suggested above in regard to the Open Market Committee's relationship to its staff. If the economy performs in a patently undesirable way, is that the fault of monetary policy? or was monetary policy appropriate ex ante and the poor outcome due to unforeseeable circumstances beyond Federal Reserve control .. like a surprise price increase imposed by the OPEC cartel, or a stock market crash that dampened the public's spending, or credit stringency following large loan losses taken by banks and other lenders?

But much of the motivation for a more intermediate monetary policy decision making framework has also been internal, in the simple sense of enhancing the likelihood of achieving more desirable ultimate outcomes. Regardless of whether it is left to staff or carried out by principals, and regardless too of whether the matter is drawn explicitly or merely left implicit, the process of establishing the policy instrument that is most likely to lead to any desired 
central banks can and do observe.

The specific aspect of intermediate behavior that has traditionally received the most attention in this context is the accumulation of money balances. Given that the central bank's main form of policy action in a fractional reserve banking system is the purchase or sale of securities in exchange for bank reserves, even quite disparate accounts of the behavioral process connecting monetary policy to economic activity provide at least a potential role for fluctuations in some measure of "money" to anticipate fluctuations in income, output and spending (either real or nominal). In the most conventional rendering, open market purchases provide reserves that enable banks to increase their lending and thereby create more deposits, thus reducing interest rates (as long as the demand for deposits is negatively interest elastic) and so stimulating spending. A closely related alternative version places more emphasis on the Importance of bank lending in financing either tusiness or household expenditures, so that movements in money anticipate spending primarily because they reflect what is happening on the other side of the banking system's balance sheet. A quite different view focuses initially on the presumed link between money and prices, assoclating any effects on real activity with the output decisions of producers unsure of how to interpret the limited information they receive as prices change.

In each of these representations, the behavior that ultimately generates changes in real economic activity and/or prices also involves movements of "money," and if the timing is right the FOMC can exploit those movements as a means of checking, and if warranted changing, its chosen level for the federal funds rate or the quantity of nonborrowed reserves. The most straightforward way to do so is simply to compare the observed level (or growth rate) of "the money stock" to prior expectations, formulated in conjunction with the original 
economic outcome involves tracing backward a causal trail that leads (in the forward direction) from what the central bank does to what happens to nonfinancial economic activity. Along that causal trail, central bank action and economic effect are separated both by time and by behavioral process. A change in the federal funds rate or in the quantity of nonborrowed reserves nou makes a difference for economic activity later on, and the economic behavior that gives rise to that ultimate difference involves actions along the way that are, at least in principle, observable. The concept of either an intermediate target for monetary policy or an information variable rests on both the time lag and the observability of steps along the way (and, of course, on the fundamental presence of uncertainty in the first place).

It is important to emphasize the joint and mutually reinforcing role played in this context by both the passage of time and the occurrence of observable intermediate behavioral actions. If the implementation of a new federal funds rate in the morning had its full effect on income and prices by lunch time, there would be little practical interest (at least for policy purposes) in monitoring what happened along the way. Confronted by undesirable economic outcomes, the FOMC could change policy the same afternoon. Similarly, if there were no way to observe what was happening until the full economic impact of a funds rate change had occurred, the Committee would have little choice but to "wait it out" with whatever rate level seemed appropriate ex ante, even if the wait might be long indeed. In the world that confronts actual monetary policy. however, it does take time for central bank actions to achieve their full effect on economic activity. And, at least under most conceptions of how monetary policy works, the underlying economic behavior does involve steps along the way - ranging from financial actions like taking loans or making deposits, to nonfinancial actions like placing orders or obtaining building permits - that 
instrument cholce. More money (or a faster growth rate) than expected might mean that monetary policy is having a more stimulative effect on economic activity than anticipated. Or it could mean that, while monetary policy is having the anticipated effect, some independent influence - fiscal expansion, for example, or a stock market rally -. is providing more stimulus than anticipated. Elther way, the Indicated response would be to tighten monetary pollcy by raising the funds rate or reducing (the growth of) nonborrowed reserves. Such a procedure amounts to using "money" as an information variable. periodically exploiting its relationship to economic activity to make mid-course corrections in the chosen policy instrument as needed, rather than simply wait unt 11 the ultimate effect on income and prices has itself become fully evident. Under most conceptions of how central bank actions affect the economy, of course, movements in money are not always a sign of movements in income and prices to come. More money (or a faster growth rate) than expected might Instead mear that bank customers are simply choosing to hold larger deposits in place of alternative forms of wealth, for reasons unrelated to their spending or production decisions. Or it could mean that banks have decided that a smaller cushion of excess reserves is appropriate to newly prevailing market conditions. Whenever the FOMC uses "money" (or any other observable quantity or price, for that matter) as an information variable to help guide monetary pollcy, it must inevitably make fudgments about fust such matters in order to decide whether, and if so by how much, to react when the chosen information variable behaves unexpectedly. When the Committee's fudgments are right more often than not, using an information variable in this way can help it to achieve more desirable outcomes, although it does little to further the interest of those who seek to monitor monetary pollcy externally.

By contrast, the Committee could eschew making such judgments on a case by 
case basis and instead simply decide that it will always react to unexpected movements in woney as if they convey information about nonfinancial activity that warrant a change in the funds rate or in nonborrowed reserves. The limiting case of this wanner of proceeding is not only to treat all unexpected money fluctuations as informative in this sense but also, as a quantitative watter, to react to any such unexpected movements by changing the policy instrument in such a way as to offset them altogether (or to the maximum extent possible). If the FOMC had initially thought such-and-such percent money growth was consistent with achieving its objectives for income and prices, but incoming data has shown faster growth, the Commlttee would thus respond by raising the funds rate or withdrawing reserves to the extent now thought necessary to restore money growth to just that originally designated rate. In this case, the Comittee would be using money not merely as an information variable but, further, as an Intermediate target - In the sense that it is, for some period of time, conducting monetary policy as if its objective were not to influence nonfinancial economic activity but to achieve a designated rate of money growth (which, of course, is wore straight forward for outsiders to monitor).

But for what period of time is that? In the vast literature discussing targets and instruments of monetary policy, analysis of this kind of intermediate target procedure typically does not designate any specific time interval for which the intermediate target is in force. For purposes of formal analysis, doing so is perhaps beside the point. But the substantive force of an intermediate target depends crucially on the length of time during which achieving a particular target actually governs the conduct of policy.

For example, suppose the FOMC determines that achieving its objectives for nonfinancial economic activity is likely to be consistent with money growth of such-and-such percent, and further resolves not to revisit this water for the 
next year. Instead, during that time it will conduct open market operations solely with an eye to achieving its chosen rate of money growth. Such a practice would clearly distinguish this use of money as an intermediate target, not just as a formal matter but in substance as well. Throughout the year the Comittee would, in effect, be conducting policy under the presumption, quantitative as well as qualitative, that the open market response appropriate to offsetting any unexpected movements of money is also the response appropriate to offsetting any unwanted fluctuations in nonfinancial economic activity.

By contrast, suppose the Comittee adopts what is formally the same stance but also resolves to revisit the matter, including making a fresh assessment of whether the initially designated money growth rate is still consistent with the desired nonfinancial outcomes, after just one month. Here money may still be the intermediate target of monetary policy, in the sense that its movements govern open market operations within that month. But as a substantive matter the Committee is addressing, regularly and frequently, the very same questions - to what extent does the latest movement in money say anything about income or prices? and what rate of money growth now seems most consistent with achieving whatever is now the desired path of income and/or prices? - that arise when money is just an information variable.

As a substantive matter, therefore, whether the designation of a specific intermediate target for monetary policy really amounts to what the literature has associated with such a procedure depends importantly on the length of time for which it is in force. In one direction, longer time intervals give the intermediate target procedure substantive content. Indeed, as the interval becomes long enough, pursuing an intermediate target becomes indistinguishable from following a fixed money growth rule without feedback. In the other direction, shorter time intervals render an intermediate target substantively 
equivalent to an information variable.

Just where today's FOMC practice stands along this spectrum is ambiguous. As a rhetorical matter, under the Humphrey-Hawkins legislation the Committee reports targeted growth rates (actually ranges) to Congress for an entire year at a time, with an opportunity to revise these targets at wid-year. A year is presumably long enough to lend substantive content to an intermediate target procedure in this context. As a practical matter, however, both the observed outcomes and the Chairman's statements to Congress clearly show that the Committee feels no imperative to meet its designated targets if it judges doing so to be inappropriate. In this presumably more important sense, money is clearly serving as (at most) an information variable, not an intermediate target.

Regardless of whether the Committee uses "money" - or any other variable - as an intermediate target or just an information variable, however, two basic requirements remain. The quantity or price in question must be observable. And its movements must provide information about subsequent movements of income, or output, or prices, or whatever aspect of nonfinancial economic activity monetary policy seeks ultimately to affect. When changes in market structures or practice render a variable unobservable (as implied, for example, by the familiar claim that there is some concept of "money" that continues to be closely related to income or prices, but whish does not correspond to any measure that could be revealed by the available data), or when such changes sever a variable's empirical relationship to nonfinancial economic activity so that its movements are no longer predictive, that variable's usefulness for purposes of monetary policy is ended. But on both counts, that is an empirical matter. 


\section{Evolving Markets and Changing Empirlcal Relatlonships}

Financial markets, both in the United States and elsewhere, have undergone vast changes over time. In the United States during the past two decades, the markets for deposits and deposit-like instruments have been a particularly dramatic focus of change. Banks, thrifts and other competing institutions, acting in response to relaxed government regulation as well as to new opportunities opened by technological advances in communications and data processing, have widely introduced new forms of wealth holding that elther did not exist at all, or at best were avallable only by spectal arrangement for very large accounts, fust a short time before. The deposit-holding public, including businesses as well as household accounts both large and small, have responded in turn by massively shifting their patterns of deposit ownership. All this is, by now, highly familiar and well documented. 2

From the perspective of what matters for monetary policy, the single most fundamental aspect of this sweeping change in deposit institutions has no doubt been the abolition. virtually at a stroke, of the long-standing distinction between saving balances and transactions balances. At least since the 1880 s (Jevons, for example), economists have distinguished the desire to hold money as a repository of wealth from the desire to hold money as a means of consumating purchases. And at least since 1933, when the Glass-Steagall Act prohibited payment of interest on demand deposits, this conceptual distinction had corresponded in the United States to a readily visible division between different forms of deposits actually offered by banks. But in the new world of money market mutual funds, money market deposit accounts, and other instruments combining market-related interest rates and checking services, it is now standard practice for depositors to make the same account balance serve both functions. 
Nor has the scope of change within the last decade or two been limited to institutions and practices affecting the public's asset holding behavior. Borrowing arrangements, too, have become sharply different. The change in this regard that has probably been of greatest significance to links between monetary policy and nonfinancial economic activity is the securitization of residential mortgages and subsequent establishment of a highly liquid secondary market for the resulting securities. This development has effectively severed the link between mortgage financing and deposit flows, a link that had previously enabled the Federal Reserve (acting in confunction with other regulatory bodies) to exert particular influence over the pace of homebuliding by setting market interest rates either above or below the maximum interest rates legally payable on deposits. The ceilings that used to limit deposit interest rates are now mostly gone, but in all probability their presence today would make little difference for the cyclical variability of homebulding because securitization has made available to mortgage borrowers virtually the entire market of saving flows, not just those that pass through depository intermediaries.

The more general erosion of the position of depositary intermediaries, of which mortgage securitization is just the most obvious example, is potentially of paramount importance for the way in which the Federal Reserve System conducts monetary policy. At least under current institutional arrangements, the Federal Reserve's functional role in this context is as the monopoly provider of reserves in a fractional reserve system encompassing banks and other depositary intermediaries. But if the intermediary sector itself atrophies in relation to the economy's overall systems for holding wealth, executing transactions and mobilizing saving to finance expenditures, that functional role correspondingly withers in its importance and effectiveness for the determination of nonfinancial economic activity. 
Figure 1 shows that the share of total wealth holding in the United States represented by depository intermediarles' liabilities has recently declined sharply (mostly because of the collapse of the savings and loan industry), after well over a decade of relative stabllity. Even so, these institutions' share in total wealth holding is approximately what it was two decades ago, and well above what it was three decades ago. By contrast, Figure 2 shows that the share of debt financing done by deposttory intermediarles has been declining for the last two decades, and at a more rapid rate in recent years. These institutions' share in total debt financing is well below any recent benchmark.

No one knows just how small reservable (or potentially reservable) deposits must become in relation to total wealth, or how small the assets of depository institutions must becone in relation to total credit, before the central bank's ability to affect these institutions' behavior by providing reserves no longer translates into an ability to affect broader aspects of economic activity. But the limiting point is surely not zero, and it is implausible not to expect the relevant associated relationships to change, perhaps subtly but perhaps more dramatically, well before that point is reached.

And change they have. Table 1 reports the results of standard empirical exercises testing whether the respective growth of any of the usual money or credit aggregates conveys information about nominal income growth in the United States, apart from what is already known from past income growth itself and from past movements of the federal funds rate. The table presents F-statistics for tests, based on quarterly data across different time periods, of the null hypothesis that all of the coefficients on the lagged growth of the specific aggregate indicated (that is, all of the $\beta_{i}$ ) are zero in autoregressions of the form 


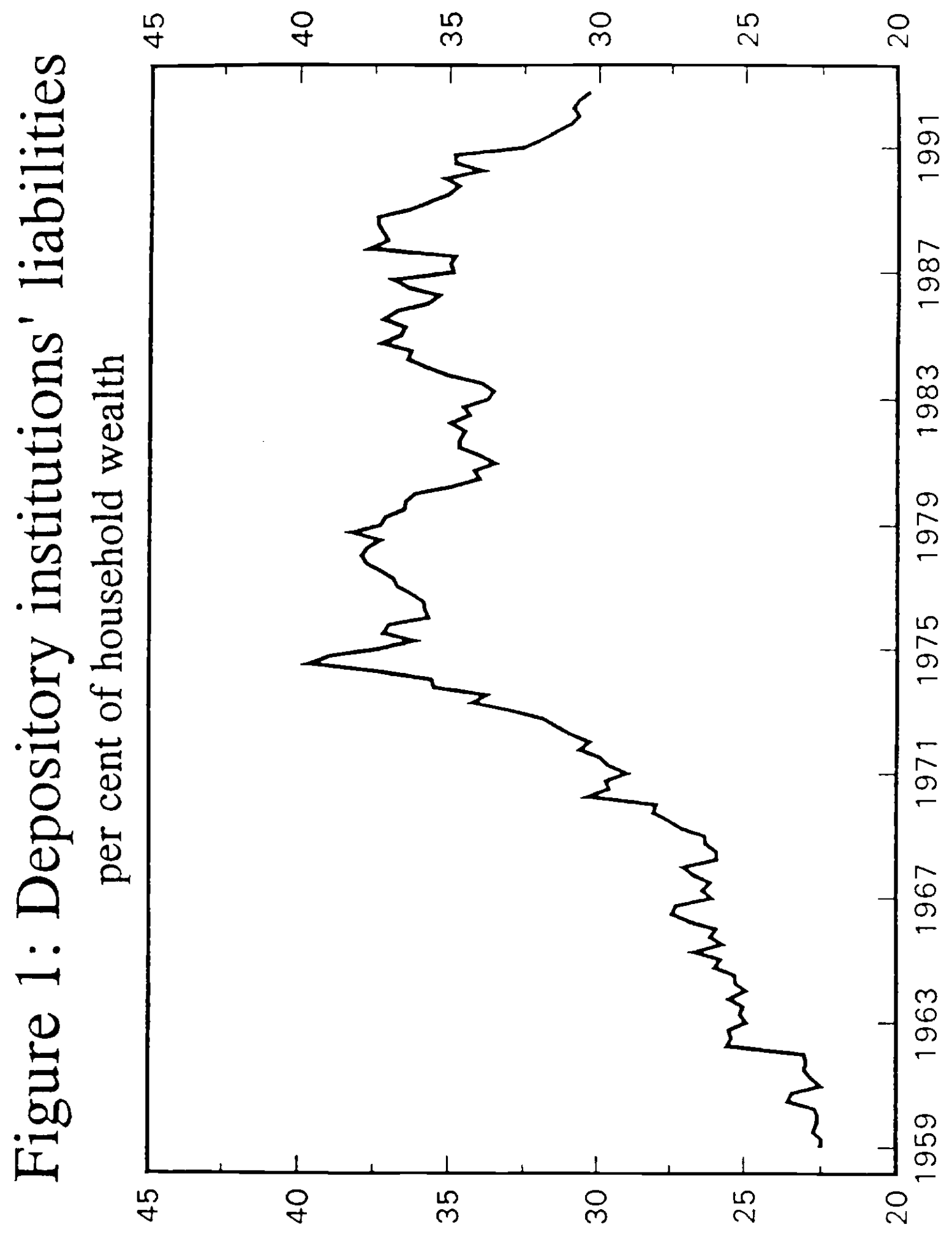


TABLE 1

E-STATISTICS IN NOMINAL INCOME EQUATIONS

Note: Estimated regressions include four lags on each of nominal GDP, the federal funds rate and the aggregate shown. Nominal GDP and the aggregate are expressed in logarithms. All variables are in first differences.
$\star \star \star \quad$ significant at the 01 level
$\star \star \quad$ significant at the .05 level
* significant at the .10 level 


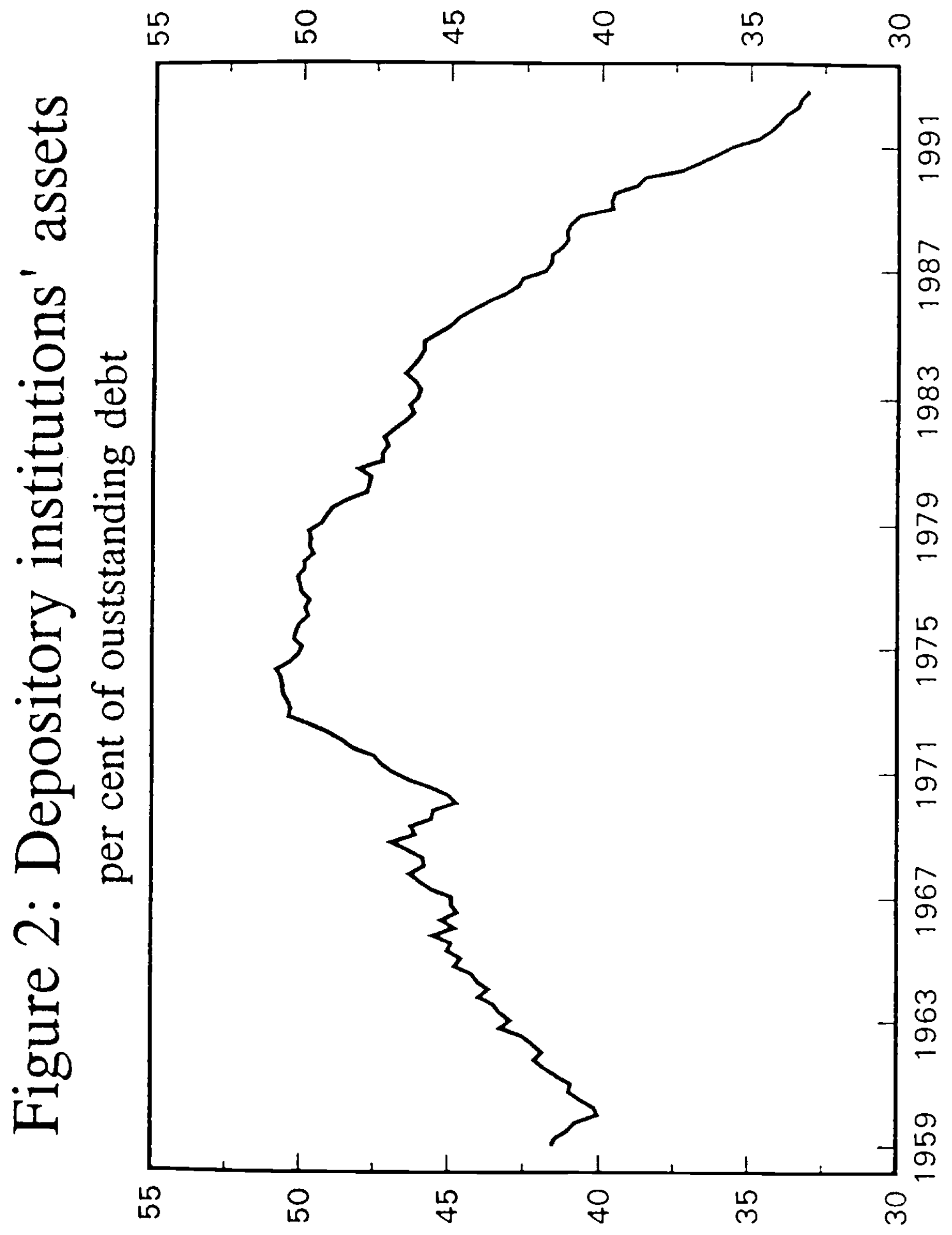


(1) $\Delta y_{t}-\alpha+\sum_{i=1}^{1} \beta_{i} \Delta m_{t-i}+\sum_{t=1}^{1} \gamma_{i} \Delta r_{t-i}+\sum_{i=1}^{1} \delta_{i} \Delta y_{t-i}+u_{t}$

where $y$ and to are, respectively, the logarlthms of nominal gross domestic product and the aggregate Indicated; I is the federal funds rate; $u$ is a disturbance term; and $\alpha$ and the $\beta_{1}, \gamma_{1}$ and $\delta_{1}$ are all coefficients to be estimated. ${ }^{3}$ The five aggregates considered are the narrow (M1), broad (M2) and broader (M3) money stocks, bank loans, and total debt of domestic nonfinancial borrowers.

The first time perlod considered in Table 1 is 1960:2-1979:3, that is. from the earliest time for which the Federal Reserve provides data corresponding to its current definitions of the monetary aggregates until the point when $1 t$ introduced new operating procedures for monetary policy. The end of the 1970 s also marked the approximate onset, or the acceleration, of many of the changes in private-sector financial markets that have distingulshed the more recent period. As the F-statistics presented in the table make clear, during 1960-79 each of the five aggregates considered contained information about future nominal income movements that was statistically significant at the .10 level or. in most cases, better. By contrast, for the perlod since then (1979:4-1992:4) not one of the five aggregates does so. Further, this sharp difference is not simply an artifact of the shortness of the second sample. Except for M3, which Is just significant at the .10 level, the same result emerges when the time period under consideration also includes the entirety of the 1970 s $(1970: 1-1992: 4)$.

The scope and Import for monetary pollcy of changes like those documented in Table 1 should not be underestimated. For the FOMC to use any of these aggregates even as an information variable, much less as an intermediate target. 
it must know qualitatively that a relationship between the aggregate and nonfinancial economic activity exists and it must know at least something quantitatively about what that relationship is. If the F-statistics for 1979-92 (or even 1970.92) showed the existence of such relationships, then the relevant questions for policy purposes would be whether they were the same as (or similar to) the ones that had prevalled earlier on, and if not then whether (or how) the Open Market Comittee in the past could have inferred the new relationships once they were established, and whether the Committee can now have sufficlent confidence in these reiationships going forward to exploit them for policy purposes. But since the F-statistics in fact show no such relationships in the first place, none of these questions arises, and certainly not the issue of exploitation for purposes of monetary policy. What could it mean to use an information variable that provides no information? Or to have an intermediate target that is not demonstrably intermediate? What is left of the familiar argument that monetary policy should be conducted according to fixed rules in order to render the economic environment more predictable for private economic decision makers, if the economic outcomes that matter to private decision makers bear no predictable relationship to the variable on which the monetary policy rule is based?

It is always possible, of course, that any or all of these aggregates may bear a usefully informative relationship to the movement of either real income or prices separately, but that that relationship is obscured here by combining real income and prices into the single measure of nominal income. Traditionally, the most fundamental theory of "money" in economics has emphasized the link to prices, leaving implications for real activity to more specific treatments embcdying impediments to Walrasian equilibrium that may be realistic but rest on weaker foundations nonetheless. 4 By contrast, much of the 
fluctuations in money anticipate fluctuations in real output. ${ }^{5}$ Either kind of relationship would potentially be useful for purposes of monetary policy, in that the FOMC as a standard matter indicates its concern for both price inflation and real outcomes.

As Tables 2 and 3 show, however, such is not the case. Table 2 presents F-statistics, analogous to those in Table 1 , for the $\beta_{i}$ coefficients in autoregressions of the form

(2) $\Delta x_{t}-\alpha+\sum_{i=1}^{4} \beta_{i} m_{t-1}+\sum_{i=1}^{4} \gamma_{i} r_{t-i}+\sum_{i=1}^{4} \delta_{i} x_{t-i}+\sum_{i=1}^{4} \phi_{i} p_{t-i}+u_{t}$ where $x$ and $p$ are the logarithms of real gross domestic product and the corresponding price deflator, respectively, and all other variables are as in (1). Table 3 presents analogous F-statistics for a further set of autoregressions that are identical to (2) except that $p$ replaces $x$ as the dependent variable. As is well known, none of these aggregates conveys statistically significant information about subsequent movements of real income once the relationship allows for the effects of interest rates (here represented by the federal funds rate). That was true before 1980, and it has been true since. Before 1980 most of these aggregates did convey such information about subsequent movements of prices. (Interestingly, M2 is the exception.) In more recent samples only M3 and (surprisingly) bank loans have done so.

Changes of the scope and magnitude illustrated in Tables $1-3$ are unlikely to be mere accident. Instead, these changes in statistical relations have more likely resulted from changes in economic behavior, presumably including .. and perhaps especially including .. just the kind of changes in financial market structure and practice that are at issue here. 
TABLE 2

F-STATISTICS IN REAL INCOME EQVATIONS

Ml

M2

M3

Loans

Credit
.82

.92

1.18

1.18

.55
1.18

1.32

.65

.14

.18

.10

.55

.22

.59

Note: Estimated regressions include four lags on each of real GDP, the GDP price deflator, the federal funds rate and the aggregate shown. Real GDP, the deflator and the aggregate are expressed in logarithms. All variables are in first differences.

\footnotetext{
$\star \star \star \quad$ significant at the .01 level

$\star \star \quad$ significant at the .0S level

* significant at the . 10 level
} 
TABLE 3

\section{E.STATISTICS IN PRICE EQUATIONS}

\begin{tabular}{|c|c|c|c|c|}
\hline AGGREGATE & \multicolumn{2}{|c|}{$1960: 2-1979: 3$} & $\underline{1979: 4-1992: 4}$ & $1970: 1-1992: 4$ \\
\hline$M 1$ & & $4.99 * \pi \star$ & 1.06 & .38 \\
\hline$M 2$ & & 1.44 & 1.33 & 1.34 \\
\hline M3 & & $2.22 \star \star$ & 1.13 & $2.96 \star \star$ \\
\hline Loans & & $3.85 \star \star \star$ & $2.73 \star \star$ & $3.60 \star \star \star$ \\
\hline Credit & & 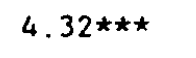 & .55 & .65 \\
\hline Note: & $\begin{array}{l}\text { Estimated reg } \\
\text { real GDP, the } \\
\text { rate and the } \\
\text { and the aggre } \\
\text { variables are }\end{array}$ & $\begin{array}{l}\text { gressions } \\
\text { e GDP price } \\
\text { aggregate } \\
\text { egate are } \\
\text { e in first }\end{array}$ & $\begin{array}{l}\text { include four lags } \\
\text { e deflator, the fe } \\
\text { shown. Real GDP, } \\
\text { expressed in logar } \\
\text { differences. }\end{array}$ & $\begin{array}{l}\text { on each of } \\
\text { ederal funds } \\
\text { the deflator } \\
\text { rithms. All }\end{array}$ \\
\hline $\begin{array}{l}\star \star \star \\
\star \star \\
\star\end{array}$ & $\begin{array}{l}\text { significant } \\
\text { significant } \\
\text { significant }\end{array}$ & $\begin{array}{l}\text { at the } .01 \\
\text { at the .05 } \\
\text { at the .10 }\end{array}$ & $\begin{array}{l}\text { level } \\
\text { level } \\
\text { level }\end{array}$ & \\
\hline
\end{tabular}




\section{Three Case Studies}

As a means of illustrating the connection between the changing statistical relationships documented in Section II and speciflc changes in financial market structure and practice, it is helpful to fous in more detail on three of these aggregates in particular.

Narrow meney. Two decades or so ago, the center of attention among economists and others who advocated a greater role for monetary aggregates in the making of U.S. monetary policy was the narrow money stock (MI), consisting essentially of currency and demand deposits. The reasons were theoretical, practical and empirical. The theory of the demand for money for transactions purposes seemed well worked out, especially in comparison to the more open-ended issues involved in demand for money as a means of wealth holding. As a practical matter, it was straight forward that currency and demand deposits were the two main ways of effecting transactions in the United States. By contrast, endless debate and ambiguity surrounded any attempt to draw a line separating what was "money" from what wasn't for portfolio purposes. Finally, although Friedman and Schwartz's (1963) historical work had used a broader aggregate also including savings deposits at commercial banks (but not thrifts), widely publicized studies by Andersen and Jordan (1968), Goldfeld (1973) and others seemed to point to $M I$ as the measure exhibiting greatest stability in relation to income in the United States during the post World War II period.

As a result, MI usually assumed pride of place in the FOMC's on-again off-again attempts, beginning in 1970, to incorporate monetary aggregate targets (or constraints, or provisos) in its regular directives to the trading desk. When the Committee dramatically adopted new operating procedures in October 1979, much of what the change was all about was a heightened emphasis on achieving targeted rates of money growth. Again Ml was the main focus of 
attention.

At the same time, it was well understood that the then existing structure of reserve requirements, under which banks held reserves against not only demand deposits but also savings deposits, weakened the Federal Reserve's potential control over Ml. The Federal Reserve in 1978 had proposed a new system of reserve requirements focused more narrowly on "transactions" balances, and also introducing reserves against such balances on account at nommember banks and even at nonbank intermediaries., ${ }^{6}$ Congress legislated approximately this system as part of the Monetary Control Act of 1980.

Ironically, just as the Federal Reserve was placing $M 1$ at the center of 1 ts monetary policymaking framework and the Congress was revamping reserve requirements to make $M I$ more closely controllable, the relationship between $M I$ and nonfinancial economic activity had already begun to break down. Following a widely debated eplsode at the end of the 1973-75 recession, in which business recovered sharply despite $M 1$ growth that normally would have been consistent with a much slower advance of nominal income (to the evident consternation of the Federal Reserve's critics), Goldfeld (1976) added to his earlier paper a postscript wondering where the "missing money" was. By the time the FOMC formally abandoned its new operating procedures, Judd and Scadding (1982) were already in print with a survey article citing more than elghty papers on the apparent demise of the money demand function and the ongoing effort to rescussitate it.

As Figure 3 shows, however, these events of the mid to late 1970s, troublesome as they were at the time, now appear as mere blips compared to what has happened since. The reason, presumably, is the revolution in ways of effecting transactions that began with the introduction of Now accounts (in New England only) and money market mutual funds, assumed full force following the 


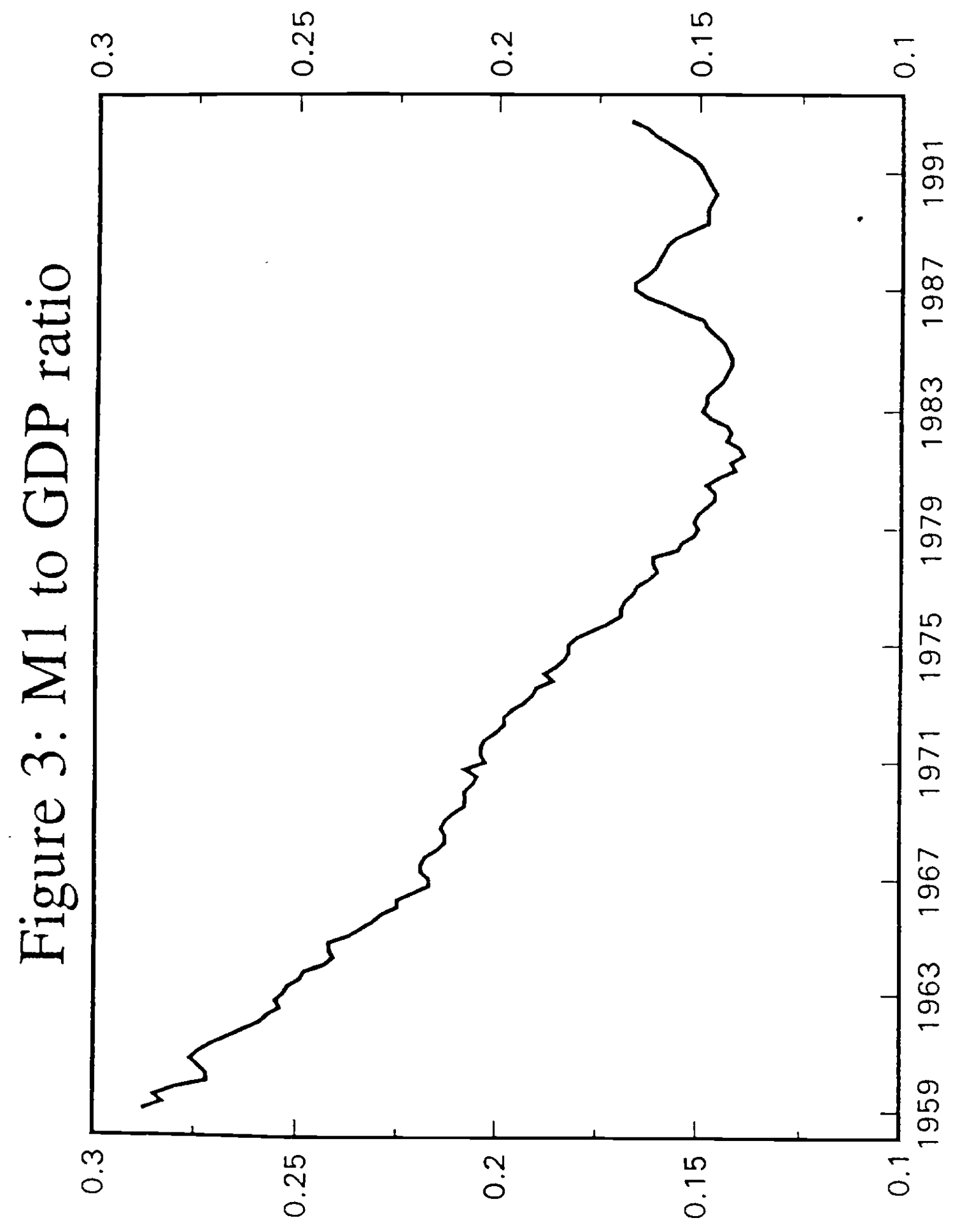


Depository Institutions Deregulation Act of 1980, and has since continued with the introduction of "debit cards."

Few people would have expected the demand for any transactions centered monetary aggregate to remain unaffected by these developments (the Federal Reserve redefined $M I$, together with the other standard aggregates, in 1980), but many falled to anticlpate the full extent of the collapse of Ml's relationship to both income and prices. For example, well after the Federal Reserve had publicly abandoned 1 ts close adherence to money growth targets, Milton Friedman (1984) argued that the short-run relationship of $M 1$ to nominal income remained as rellable as before but had merely accelerated the time lag involved, and moreover that the longer-run relationship of $M l$ to prices also remained predictive. As Table 1 shows, however, there is no statistically significant relationship between $M 1$ and nominal income in the post-1979 data. Table 3 shows the same for prices. Even the correlation between $M 1$ growth and inflation, computed in the way friedman recommended to bring out the longer-run relationship (using two-year moving averages to smooth out transitory fluctuations, and a two-year lag to allow for sluggish price responses), dropped from .87 during $1959-78$ to .10 during 1979-92.

Beginning in 1983, the FOMC not only widened the $M 1$ target range 1t reported to Congress but also stated explicitly that it was placing less emphasis on $M I$ than on broader aggregates. In 1986 the Committee widened the MI target range to flve percentage points. In 1987 the committee gave up reporting any $\mathrm{Ml}$ range at all.

Broad credit. In the late 1970 s and early 1980s. I wrote a series of papers showing that the total outstanding debt of all nonfinanclal U.S. obligors bore a relationship to nominal income comparable to that for any of the standard monetary aggregates (see again the $1960-79$ column of Table 1 ). ${ }^{7}$ At the most 
basic level, the motivation for this effort was the fact that skeletal macroeconomic models like those of Tobin (1969) or Brunner and Meltzer (1972) conveyed no a priori presumption that one side of any sector's balance sheet be more intimately related than the other side to its nonfinancial activity. Liabilities could be just as relevant as assets. At a more substantive level, many of the disparate strands of what has since come to be called the "credit viewn of monetary pollcy at least had in common a focus on economic agents' ability to borrow.

Two aspects of this work were somewhat surprising, however, especially in the context of "credit view" thinking. First, the debt aggregate that bore a statistically significant relationship to income - that is, the aggregate whose fluctuations tended to anticipate future movements of income - Included both the debt of private-sector borrowers and government debt (unlike the corresponding private-sector-only measure, a form of which had for some time been an element of the standard index of leading indicators). Second, in contrast to the usual "credit view" implication that there is something special about the debt of banks, or perhaps of banks together with other credit granting intermediaries, total credit consistently outperformed any bank-based measure in statistical tests of a relationship to income. While these specifics raised some puzzles to be explained, that did not take away from the fact that at least one measure of the economy's liabilities was as closely related to nonfinancial economic activity as any measure of its assets that could be labeled "money."

When a central bank uses an explicit intermediate target as the focus of monetary policy, there can be only one such target. 8 But when the central bank uses variables like money as information variables, there is no reason to limit the procedure to just one. Given the roughly equivalent performance of total credit with any of the standard M's in providing information about subsequent 
fluctuations of income, the conclusion I drew from these results was that if the FOMC were going to use a monetary aggregate to guide monetary policy it should also use total credit for this purpose. Not only were two sources of Information likely to be better than one, b:t one monetary aggregate together with one credit aggregate also seemed preferable to using two different monetary aggregates in tandem (which some people at the time were suggesting). Using both a monetary aggregate and a credit aggregate would broaden the range of Information thus brought to bear on the monetary policy process to encompass nonfinancial agents' llabllity-1ssuing behavior as well as their asset-holding behavior. In 1983 the Fomc began to Include in its reports to Congress a monitoring range for total credit (which it calls "domestic nonfinancial debt"). and it has done so ever since.

As Table 1 shows, the collapse of the relationship between credit and nonfinancial economic activity has been just as dramatic as that for any measure of money. Figure 4 further lllustrates the enormous break with prior debt-1ssuing patterns that began not long after the 1981-82 recession ended. Roughly one-third of the rise since then in total credit compared to income has reflected the federal government's by-now chronic fiscal Imbalance. The dozen years since 1980 comprise the only sustained period since the founding of the Republic in which the U.S. Government's outstanding debt has risen faster than the national income. In 1980 the government's debt amounted to 26 cents for every dollar of U.S. gross domestic product. By 1993 1t was 53 cents.

The other two-thirds of the increase in total debt in relation to income reflects the borrowing of both businesses and households. While the government's rising debt is a matter of fiscal policy (at least in the first instance). the explosion of private-sector borrowing is very much the stuff of changing financlal market structures and practices. The most dramatic changes 


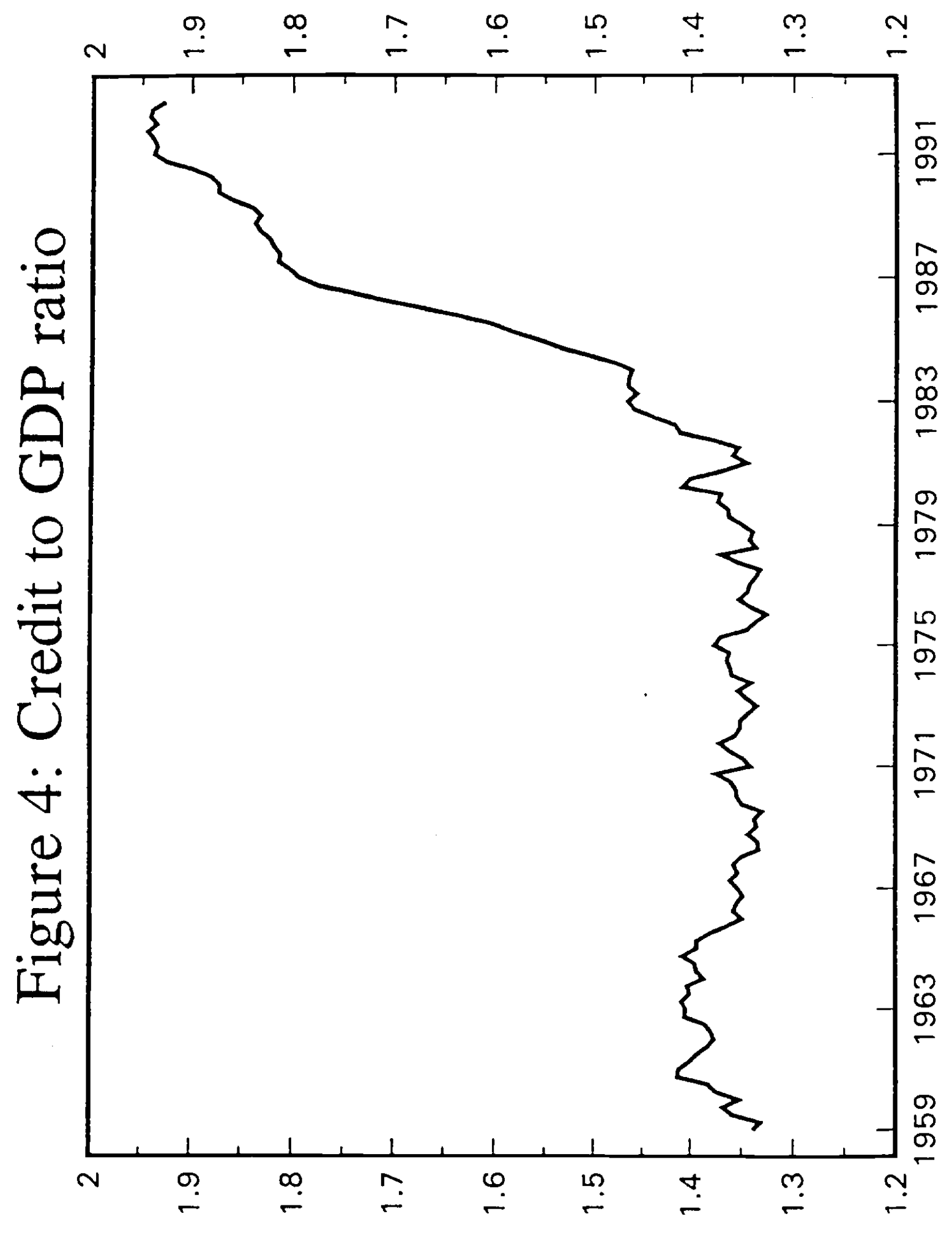


In this regard have been in the business arena, where the wave of leveraged buy-outs, debt-financed acquisitions and stock repurchases that dominated corporate America during much of the 1980 s clearly stands as an object of interest in 1 ts own right. So too does the development of the "gunk" bond market, which made so many of these transactions possible. Between 1984 and 1989 U.S. nonfinancial corporations borrowed (net of repayments) over \$1 trillion. Roughly $\$ 600$ b111ion of that went into transactions that extingulshed the equity elther of the borrowing corporations themselves or of other companies they were acquiring.

Market structures and practices affecting household borrowing have changed as well. The most obvious and presumably the most important example here is the securitization of residential mortgages, already discussed above. The markets have also securltized other household sector liablittes, however, including automoblle loans ("CARS") and credlt card obligatlons ("CARDS"). These changes have clearly increased households' abflity to borrow. Examples of institutional change that have plausibly increased households' w111ngness to borrow include the relaxation of bankruptcy requirements in varlous states. (By contrast, changes in the tax code since 1980 have mostly reduced the attractiveness of borrowing by individuals.)

In light of these pervasive changes affecting government, business and households, the collapse of the credit-to income relationship documented in Table 1 and Figure 4 is hardly astonishing.

Broad money. To the extent that support exists today for the use of any of the conventional monetary aggregates as an intermediate target for monetary pollcy, the aggregate of cholce seems to be the broad money stock (M2). 9 Within the Federal Reserve System. Felnman and Porter (1992) have argued on emplrical grounds that $M 2$ demand not only is more stable than the demand for other 
standard M's but also that M2 outperforms potentlal new candidate measures (for example, what others have called "liquid M2," consisting of currency plus all deposits in $M 2$ that can be redeemed at par on demand). Outside the Federal Reserve, Ramey (1993) and Feldstein and Stock (1993) have argued that different forms of error correction procedures render stable the ratio of M2 to money (or. in recipriocal form, the mis-named $M 2$ "velocity"). In recent years the Federal Reserve's reports to Congress under the Humphrey-Hawkins legislation have also attached more Importance to $M 2$ than to other aggregates, at times suggesting that relationships based on $M 2$ may now be settling into a new, more usefully exploitable stability after a period of disequilibrium due to changing market structures.

The performance of $M 2$ during the most recent business cycle has been anything but reassuring, however. As Figure 5 shows, M2 growth peaked in late 1986 and by yearend 1987 had slowed to rates that would normally represent a strong prediction of recession. Growth of M2 revived in 1988, faltered again in early 1989, but then revived even more strongly beginning in mid 1989 onward, so that by the time the recession began at midyear 1990 M2 was giving the opposite signal. Throughout this period M2 gave false signals broadly similar to those given by other familiar business cycle indicators like the federal funds rate, the slope of the yield curve, and the spread between the commercial paper rate and the Treasury bill rate. As is evident in Figure 5, however, the difficulty with M2 has also persisted well into the recovery, with slow M2 growth more suggestive of renewed economic downturn than of even the modest recovery that has taken place.

Figure 6, updated from Feinman and Porter (1992), makes the M2 growth puzzle more specific by plotting M2 "velocity" against the Federal Reserve's standard measure of the opportunity cost of holding $M 2$ - that is, the 


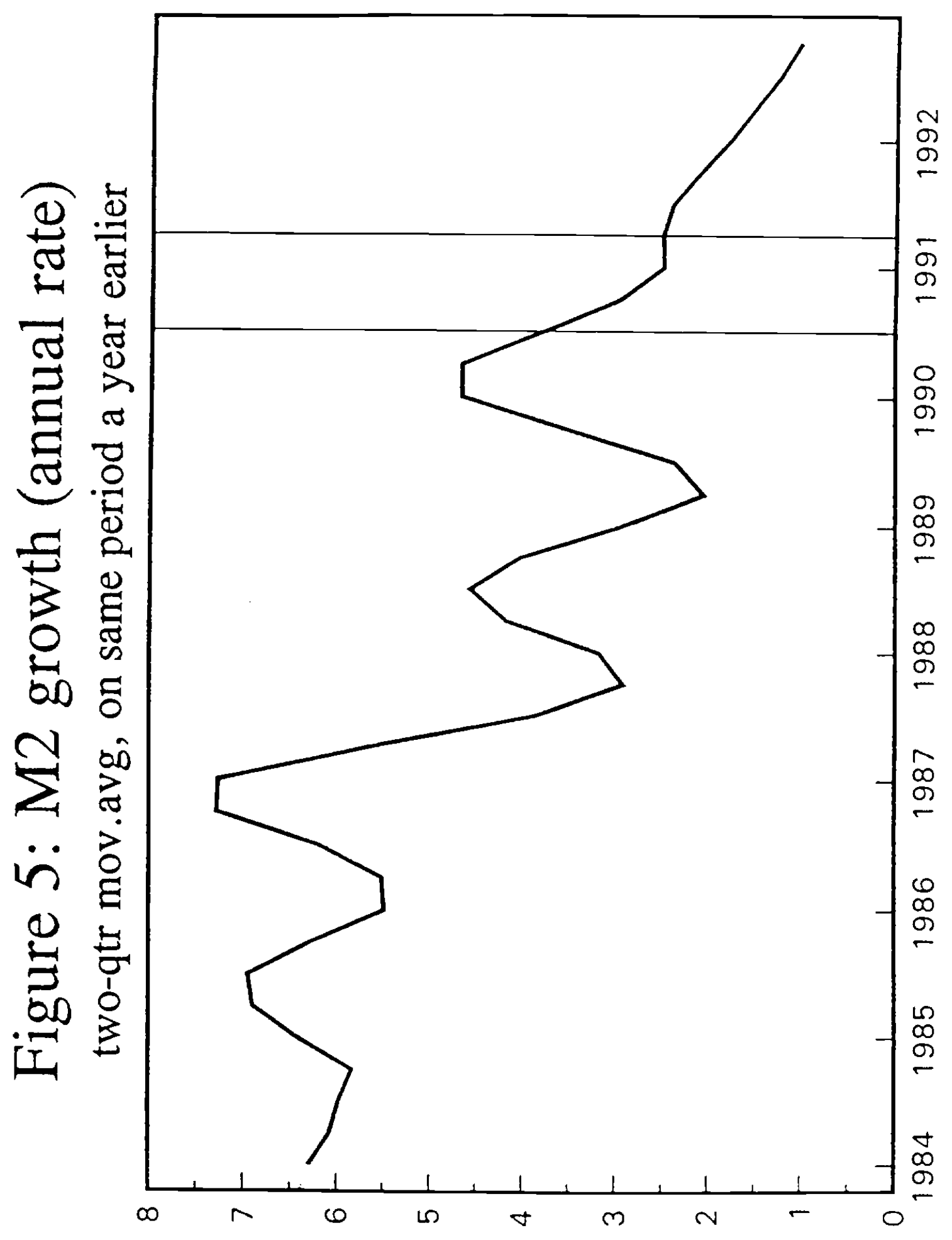




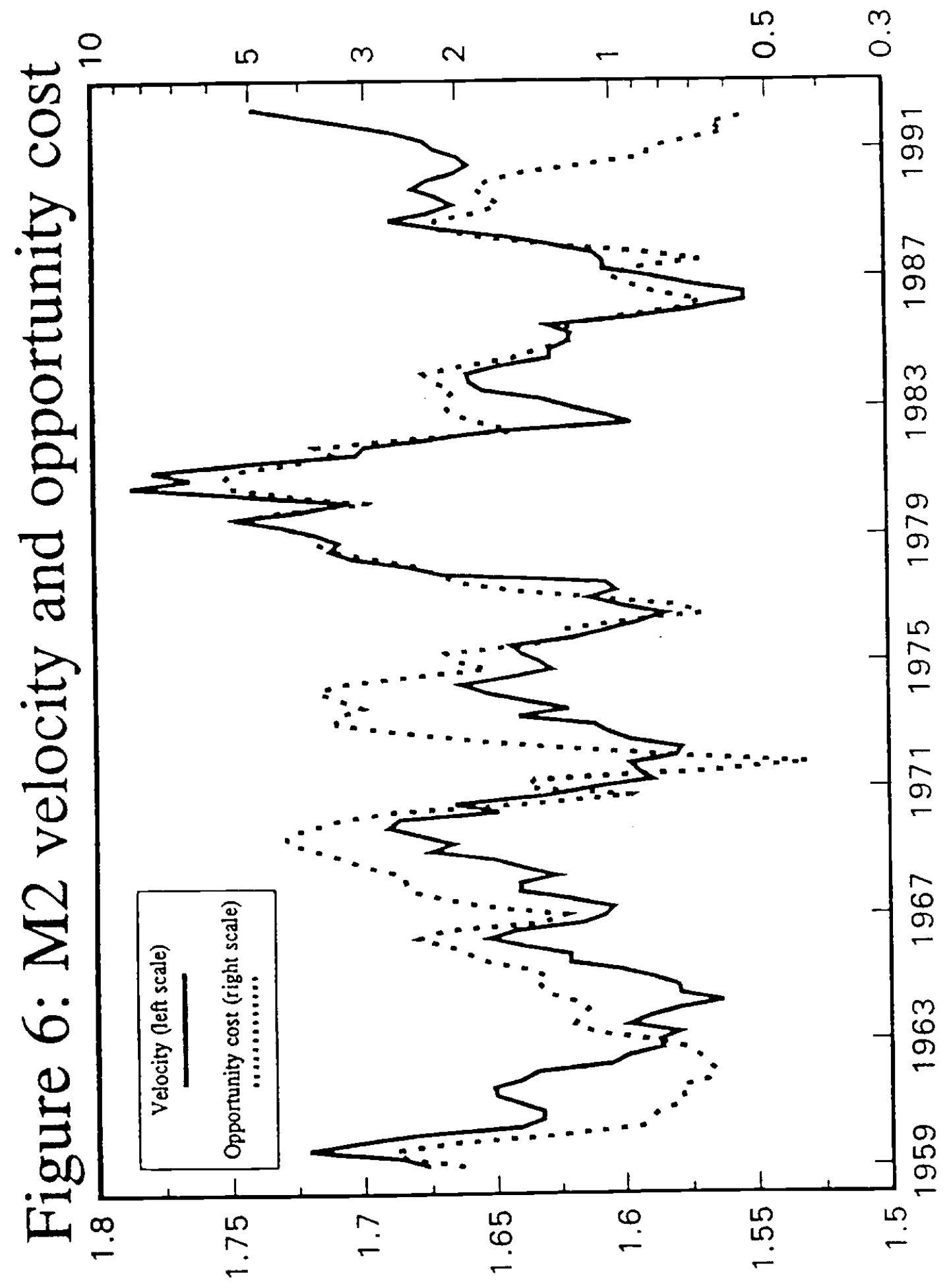


difference between the welghted-average return paid on the varlous components of M2 and a welghted-average return on short-term market instruments not included in M2. Clearly something has changed since 1988. Felnman and Porter showed that expanding the set of market instruments considered to be alternatives to $M 2$ (and, 1mportantly, choosing welghts on those instruments' returns that retrespectively maximized their explanatory power) reduced the magnitude of the recent discrepancy but did not eliminate $1 t$.

Put in the simplest way, the point of Feinman and Porter's suggested improvement in the analysis of $M 2$ demand $1 \mathrm{~s}$ that depositors may consider not Just short-term money market instruments but bonds too, and perhaps even equities, as potential alternatives to the deposit components of $M 2$. The conceptual point is hardly new, ${ }^{10}$ but there is reason to belleve that market conditions as well as the institutional response to those conditions has given it new practical relevance within just the past few years.

As Figure 7 shows, the spread between long-term and short-term interest rates has been extraordinarlly wide during the latest recession and recovery eplsode. Holders of maturing certificates of deposit therefore face a large gap between the rates at which they can renew their deposits and the current yields on bonds. (Whether those current ylelds correspond to plausible expectations of the relevant expected holding returns is more difficult to say.) At the same time that M2 has been puzzlingly weak, flows of household funds into bonds and stocks, and especially into bond and stock mutual funds, have been unusually large. Net purchases of bonds and other debt instruments by mutual funds totaled $\$ 90$ billion in 1991 and $\$ 132$ billion in 1992, compared to $\$ 33$ billion per year on average during the prevlous decade. Net purchases of equities by mutual funds were $\$ 45$ b1llion in 1991 and $\$ 67$ b1llion in 1992 versus a previous annual average of just $\$ 8$ b1llion. 11 The increasing globalization of financial 


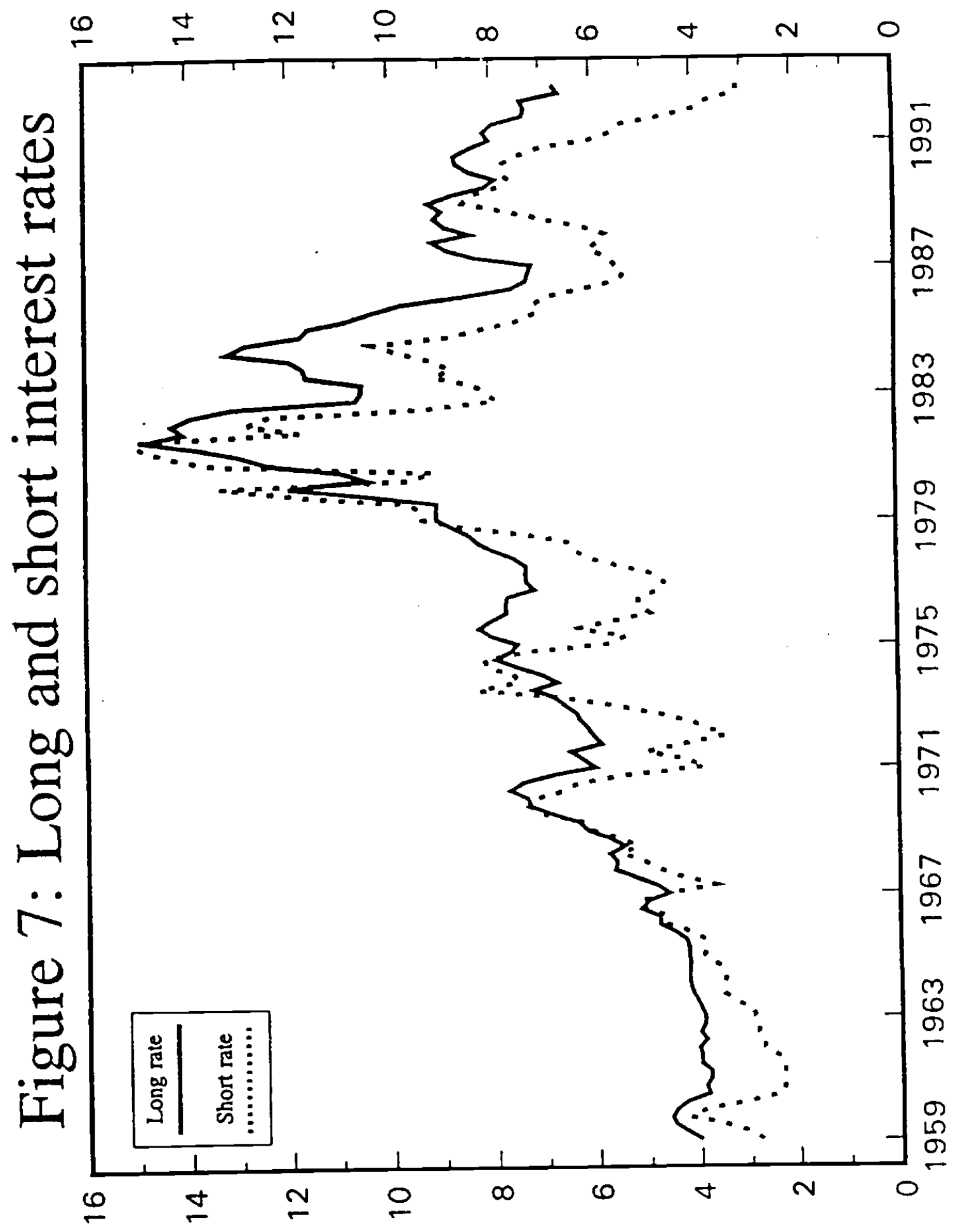


markets may also have been an influence in this regard, in that sales of mutual funds investing in forelgn bonds and stocks have grown particularly rapidly (albelt from a small base).

Not surprisingly, banks have responded to this competition by folning it A Federal Reserve survey of 56 large banks in March 1993 indicated that 52 of them offered mutual fund products to their customers, presumably as a way of at least keeping the depositor if not the deposit. Roughly one-third of these banks had begun retall sales of mutual funds just since 1990. Three-fourths of the banks marketing mutual funds as of March 1993 had sales representatives located on site at thelr branches; before 1990 half of these had no sales personnel avallable on a dally basis. The median percentage of branches with avallable sales personnel has gone from 208 in 1990 to 908 in 1993 . Among those banks that could estimate the sources of mutual fund purchases, one-third to two-thirds apparently came directly from their own deposits. 12

In addition to disrupting whatever relationships between $M 2$ and nonfinancial economic activity may previously have existed (which in 1 tself would be damaging enough), these latest changes in market structure and practice have two Implications that are especially subversive of any attempt by the FOMC to use M2 as an intermediate target for monetary policy. First, the existence of an active, quantitatively substantial margin of substitution between any measure of "money" and long-term assets greatly complicates the Comittee's task of controlling that aggregate. Indeed, as long as the aggregate in question consists mostly of short-term interest bearing instruments, it could even change the direction of the aggregate's response to open market operations.

Suppose, for example, that the Open Market Commttee seeks to Increase the rate of M2 growth (perhaps because, as in recent experfence, actual growth has fallen below the targeted range). The presumptive action by the trading desk is 
to buy securities, thereby adding to nonborrowed reserves and lowering the federal funds rate and, vla the market's response, other short-terw interest rates. The conventional expectation, based on the assumption of sluggish or even fixed deposit rates in contrast to quick-moving market rates, is an increase in money demand. But if deposit rates decline roughly in step with short-term market rates, and if substitution between deposits and longer-terw assets is quantitatively important, the demand for money may actually decifine unless (or unt11) the fall in short-term rates induces a matching fall in expected returns on the relevant long-terw assets.

As the Appendix to this section shows more formally, using the illustration of a simple model of money demand, money supply, Income determination and the term structure of interest rates, whether "expansionary" open market operations (that 1s, open market purchases) actually expand $M 2$ or shrink it depends on relationships among parameters, importantly including interest elasticlties, the estimation of which lies well beyond the scope of thls paper. How sharply the FOMC's staff has estimated those parameters (and their varlance-covariance structure) is an interesting matter about which to speculate. I conjecture that in the currently prevailing circumstances the Committee does not know with confldence even the slen, not to mention the magnitude, of the short-run response of M2 to open market operations.

The other serlously damaging implication of the new substitutability between $M 2$ and equity and bond mutual funds is that flows into or out of M2 may in the future assume the volatility that in the past has been more characteristic of securities markets. In the case of bond funds in particular, no one knows whether the Individuals who have cashed in their certificates of deposit to buy these funds have done so with a full appreciation of the risk properties of these longer-term assets. Most open-end mutual funds are 
essentially as liquid as deposits, in that holders can cash in their shares on notice. But liquidity is not the same as risk, and depending on the specific assets in the fund, the risk properties way differ sharply from guaranteed redemption at par. If at some point the new holders of bond funds suddenly discover that their shares are subject to downward price variation, redemptions triggered by a rise in long-term interest rates could easily lead to a "noise" surge in M2 demand sufficlent to overwhelm any "slgnaln the Open Market Committee would hope to explo1t by using M2 as an interwediate target.

In 1ts mid-year report to Congress under the Humphey-Hawkins procedure, in July 1993, the Federal Reserve "downgraded" the role of $M 2$ in the monetary pollcymakling process, acknowledgling that "relationships between money and income, and between money and the price level have largely broken down. "13 


\section{Implications for the Conduct of Monetary Policy}

The main lesson to be drawn frow this survey of changing relationships between familiar financial aggregates and income and prices is that there is little basis for expecting the FoMC (or anyone else, for that watter) to identify any time soon a new, stable relationship that can command the degree of confidence that was once optimistically attached to any of a variety of such aggregates, and that is required to place that relationship at the center of the monetary polfcymaking process. The point is not fust the now-familiar finding that statistical exercises devold of behavioral content show a breakdown in prior relationships. It is that this breakdown, in one case after another, has plausibly had its origin in changing financial market structures and practices and in the response to those changes on the part of households and business.

To be sure, If the financial tarkets stopped changing, then in time relationships of the kind that monetary policymakers can perhaps use to devise intermediate targets might well emerge. But why expect that to happen? A decade ago, when attention in this context mostly focused on MI, it was perhaps plausible to attribute changing money-to-income relationships primarily to changes in government regulation, and from that assumption to infer that these relationships would again stabilize as the abrupt regulatory changes of the early 1980 s receded into the past. But the point of the discussion above of credit and $M 2$ is that further change, on sbout as great a scale, took place again in the mid to late 1980 s (in the case of credit) and again in the late 1980 s to early 1990 s (in the case of M2).

Moreover, even if the financial markets did stop changing, and one or more newly stable relationships of this kind were to emerge, how long would it then take to identify those relationships both qualitatively and quantitatively? As the literature of the subject over the past two decades has amply demonstrated. 
flguring out which definition of "money" (1n other words, which collection of inherently quite different instruments) bears the most reliable relationship to income or prices is already hard enough. But for such a relationship to be genulnely useful for policy purposes, the Open Market Comittee also needs to know, at least to some reasonable approximation, its quantitative dimensions: Does this aggregate grow in proportion to income, or more so or less so? How sensitive is it to interest rates? (And which interest rates?) How different are the comovements that occur over six months from those that prevall over two years? For the foreseeable future, such difflcult but absolutely essential quantitative description is just not in the offing, at least not with any serious level of confldence.

What, then, is the FOMC to do? One possibility, of course. Is simply to fall back on whatever the Committee knows about the connections to income and prices of the instrument the trading desk sets directly - nonborrowed reserves or the federal funds rate - and make policy decistons on the basis of those ultimate relationships without drawing on any other direct inputs to the policy process. But because the lags between Federal Reserve actions and their ultimate economic consequences are fairly long (at least according to most estimates). such a bare-bones framework is inherently unsatisfying. Simply to walt it out until the full effects of any change in the funds rate have worked cheir way through to nonfinancial activity, before determining whether the new level is appropriate or not, is likely to be tantamount, in too many instances, to letting the damage accumulate.

The FOMC's central need in this situation is information: information about the economy's current state and its future direction, as well as about che effects of the Federal Reserve's own actions. And in an economic and financial environment so dominated by ongolng change, that information is harder to come 
by than ever. One implication of this basic description of the problem is that the monetary policymaking process needs to incorporate information inclusively. rather than focusing narrowly on any one variable (which would amount to discarding information from other sources). A parallel implication is that the policymaking process needs to exploit information intensively, through frequent re-examinations of just what the information provided by any one source is saying.

More specifically, the inclusive use of information presumably means using as Information variables (In the sense of Section $I$ above) not just several financial aggregates rather than only one but a broader, and potentially much broader, range of measures with potential predictive context. For example, several Federal Reserve researchers have analyzed the predictive properties of the slope of the yleld curve (that is, the term structure of interest rates) with respect to real economic activity, ${ }^{14}$ and Mishkin (1990) has documented at least modest predictive capacity of some parts of the yield curve with respect to prices. Simllarly, Kuttner and I have shown that the spread between the comercial paper rate and the Treasury bill rate contains substantial information about subsequent movements of real activity, albeit not about prices. 15 Indeed, the paper-bill spread typically remains highly significant in equations for real income even when other varlables like money and credit are introduced, and those other variables usually lose their significance altogether in the presence of the paper-bill spread.

No one would suggest using the yield curve slope or the paper-bill spread as an intermediate target of monetary policy. But once the policymaking procedure is framed in terms of information variables, rather than an intermediate target, there is no reason why interest rate relationships are any less sultable for this purpose than monetary aggregates. Just as with a 
monetary aggregate, the Open Market Committee can think through in advance how the yleld curve and the paper-bill spread are likely to move over the coming months if its policy actions are having the intended effect and if nonfinancial activity is developing as expected. And just as with a monetary aggregate, a sufficlently large unanticlpated movement of the yield curve or the paper-bili spread could be the occasion for questioning whether economic activity. either as affected by monetary policy or in other regards, is in fact developing according to plan. That, in short, is what the information variable procedure for monetary policy is all about.

There is also no analycical reason to restrict the Committee's set of formally exploited information variables to quantities or prices drawn exclusively from the financial world. Many of the observable actions that are intermediate between what monetary policy does and what it hopes ultimately to achleve take place in the sphere of real activity. Conventional leading indicator indices have always explofted the fact that goods orders, bullding permits, ground breakings and the like typlcally precede the corresponding final sales and production that account for much of an economy's output and income (although less so as the share of services in total output rises). In contrast to the unstructured use of such variables as mere leading indicators, however, for purposes of monetary policy the relevant question is also what information they contain about how effects attributable to Federal Reserve actions themselves are spreading through the economy. As is true in the case of financial quantities and prices, therefore, there is room - indeed, there is need - to choose such variables in part according to how they fit into the Committee's conception of how monetary policy affects economic activity. As a practical matter, however, it is likely that much of the substantive advantage to be gained from exploiting specific nonfinanclal variables as formal 
information variables for monetary policy is already implicit in the FOMC's existing economic forecasting apparatus. If durable goods orders, or housing starts, or container shipments move in ways seriously at odds with the Comittee's expectations for overall activity consistent with its policy stance. under current procedures that fact is unlikely to escape attention and, if warranted, close analysis. As a result, much of the concrete advantage of an explictt information variable procedure probably lies in a more inclusive exploitation of financial quantities and prices.

It is important to emphasize, however, that broadening the array of financial quantities and prices used as information variables does not guarantee superior ex post policy actions and outcomes. As Figures 8 and 9 show, for example, in the period leading up to the 1990-91 recession both the paper-bill spread and the yield curve slope gave false signals similar to those documented for $M 2$ in Figure 5. The paper-bill spread fluctuated at levels normally predictive of a recession from mid 1987 to mid 1989, then narrowed sufficiently to eliminate any indication of recession by the beginning of 1990 and did not widen again until after the recession had begun. The yield curve was a somewhat better predictor in this episode, flattening in 1988 and throughout 1989, but by early 1990 it had begun to steepen again while the recession was still a half a year away. (A widening paper-bill spread typically precedes recessions, as does a flattening yield curve.)

One interpretation of these events is simply that the paper-bill spread and the yield curve slope are, not surprisingly, imperfect as predictors of future economic activity. 16 An alternative indication, suggested by the work of a variety of recent researchers, is that these variables (like M2, perhaps) are not so much predictors of economic activity as indicators of the stance of monetary policy, and that what their movements in this latest episode reveal is 


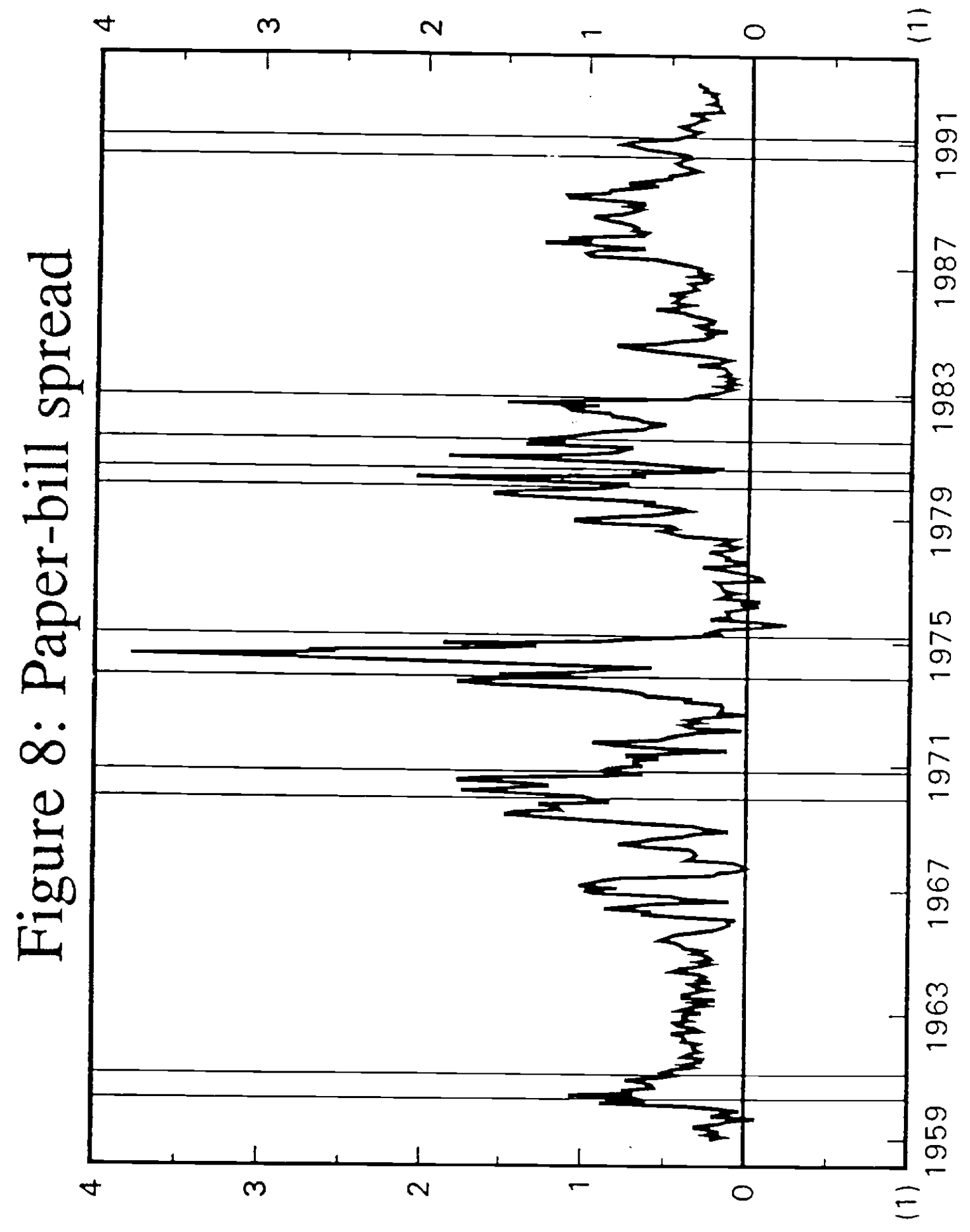




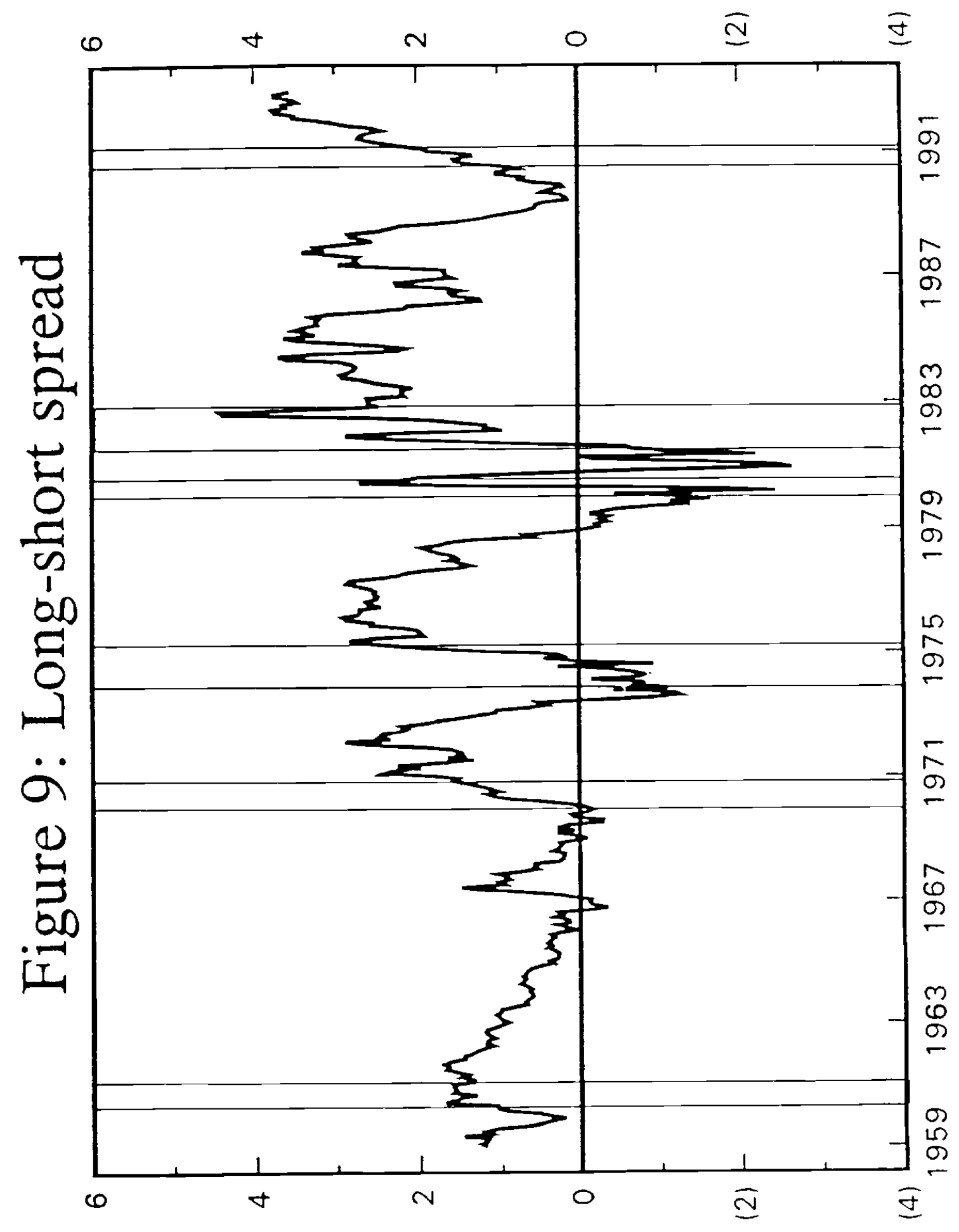


that the 1990-91 recession was due to causes other than wonetary policy (for example, the widely discussed "capital crunch" at banks and other lending institutions ${ }^{17}$ ). Much useful research remains to be done in order to establish, both for variables like these spreads and for wore conventional varlables like M2, in which of these differing lights to construe them. The distinction is central to their appropriate use in formulating and carrying out monetary policy.

Regardless of the outcome of that investigation, however, the demonstrable fallibility of variables like the paper-bill spread and the yield curve as predictors of economic activity illustrates in yet another context the advantage of using any such weasures as information variables, not intermediate targets. Unlike as with an intermediate target, an unexpected movement of an inforwation variable does not automatically trigger a change in policy in the sense of a new federal funds rate or altered growth of nomborrowed reserves. It instead creates the presumption that there is an issue to be addressed. There remains. always, the need for a judgment. This central role of case-by-casediscretion in responding to the pertinent information that arises does not mean, of course. that the FOMC should ignore the longer-run consequences of its actions. 18 It does mean, however, that ir carrying out whatever its appropriate long-run strategy may be, the Committee needs to make judgments about whether or not the movements of specific observed variables imply that it has gone off course and needs to take corrective action.

In principle, one could perhaps imagine a policy rule, based on some sufficiently complex form of intermediate target, that would internally eabody just these kinds of fudgments. After all, unless the FOMC acts in a purely random way, its monetary policy decisions do systematically reflect the Comittee's economic objectives and its understanding of how any specific action 
that it may take or not will affect the economic behavior to which those objectives relate. For practical purposes, however - as Tobin (1983) and others have emphasized -. "rules" in this context inevitably mean simple rules, not elaborate interrelationships involving large numbers of variables and multiple contingencies. Given the complexity of the relationships involved, a "rule" that fully reflected the Committee's decision making process would probably be impossible to write down. By contrast, for practical purposes of monetary policy a "rule" is not a rule unless it can be written down in one paragraph and readily explained to audiences consisting of business executives and Congressmen. Hence the need for case-by-case Judgments, as new information emerges, is real.

Finally, it should also be clear that those fudgments are best made frequently. Even the most reliable information variable can begin to give false signals, and changing financial market structures and practices can distort (compared to prior experience) the content of even those signals that continue to be informative. The experience of the last decade or so, as documented at some length and in some detall in Sections II and III above, provides ample evidence of just this phenomenon. Is it possible to know in advance that any chosen variable will necessarily provide misleading information? of course not. But that does not constitute grounds for proceeding under a strict presumption that it will not, as is inherent either in an interwediate target procedure or in. any procedure calling for automatic responses to unexpected movements of selected information variables. The presumption, instead, is that there are questions to be raised and responses to be undertaken or not in light of the best available answers. Precisely because the financial market structures and practices that matter in this regard are as subject to change as they have been in this latest period. assuming that yesterday's answer is still right today is 
at best an invitation to error 


\section{v. More Fundamental Issues}

Finally, even if the Open Market Comittee devises a successful system for formulating wonetary policy, based on a more inclusive explicit use of financial price and quantity variables and a more intensive procedure for responding to the information that these variables contain, the ongoing evolution of the U.S. financial markets as discussed in Section II nonetheless raises a broader indeed, a more fundamental -. Issue for monetary policymaking.

The most straightforward way to frame that issue is simply to ask why what the Federal Reserve System does maters in the first place. More specifically, in a $\$ 6$ trillion economy with more than $\$ 25$ trillion of financial claims outstanding in highly liquid markets where many of those claims change ownership not just easily but frequently, why should it matter whether the Federal Reserve buys $\$ 1$ bllition worth of securities or $\$ 10$ billion worth in the course of an entire year? How can such a small difference matter even for the pricing of government securities, of which there are nearly $\$ 5$ trillion outstanding, or, all the more so, for the pricing of marketable debt securities more generally, of which there are more than $\$ 12$ trillion? How especially can such a small difference in Federal Reserve transactions exert a meaningful influence on such matters as how much people choose to work or spend, or how many houses people build, or how many factories firms put up, or how much businesses produce and how they price it?

The answer, of course, is that the Federal Reserve is a monopolist. It and it alone can create the reserves that, by law, banks and other depository institutions must hold. Its purchases of securities do just that. And relative to the existing amount of bank reserves ( $\$ 57$ billion at midyear 1993), \$1 billion versus $\$ 10$ billion growth in a year is a major difference. But being a monopolist matters only if the item over which the monopoly 
applies is itself important. What if banks (and other depository institutions) can Just as easily carry out their activities - extending credit and taking deposits - without incremental reserves? And even if they can't, what if there are other institutions, like finance companies that issue credit and money market mutual funds that take deposits, to do so in their place? Questions like these have been the stuff of monetary policy economics virtually since the subject's inception. The traditionally accepted answers have been that, at least at some margin, banks cannot extend credit and take deposits without incremental reserves on the same terms that they would otherwise establish, and that, for at least some would-be borrowers and/or depositors, other institutions cannot perform these functions on the same tertos that would otherwise be avallable from banks. ${ }^{19}$ within that prevailing understanding, the ongoing debate has then focused on such subsidiary questions as whether it is the credit side of the story or the deposit side that primarily matters, whether monetary policy actions (through whatever mechanism) affect prices alone or real economic activity as well, and which specific institutions and instruments and aspects of nonfinancial activity are more central to the process than others.

By contrast, If having reserves or not is no longer important to banks, or if other lending and deposit creating institutions can readlly take their place, then the Federal Reserve's monopoly over bank reserves no longer matters. And once it does not, no one can plausibly expect even an institution with a $\$ 350$ billion portfolio (as of June 1993) to govern the evolution of prices and quantities in a $\$ 26$ trillion market, much less to exert a meaningful impact on nonfinancial economic activity.

In the United States over the last decade or so, the value of the Federal Reserve System's monopoly has apparently eroded in two senses. One, noted in 
Section III, is that because the current system of reserve requirements dates to the era (actually not so long ago) when advocates thought close control over Ml was the key to a successful monetary policy, the majority of liabilities issued by banks and other depository intermediaries are exempt from reserves. In the absence of incremental reserves, banks can and regularly do fund incremental credit creation by issuing certificates of deposit or other non-reserve-bearing instruments. This situation is readily correctable, at least in principle, although as a practical matter difficult questions of definition among forms of obligations (direct versus holding company, on-shore versus off-shore, insured versus uninsured, senior versus subordinated, and so on) would inevitably arise So too would problems of the competitiveness of the depository intermediary industry as a whole.

The harder problem is the one discussed in section II. ${ }^{20}$ The role of depository institutions collectively is shrinking in relation to the broader job being done by the financial markets overall. Without substantial empirical research that 11 es well beyond the scope of this paper, it is impossible to say just how small the depository institution sector can become, relative to economy-wide wealth holding or credit creation or saving and investment, before the Federal Reserve's monopoly even over reserves that might be imposed against the complete liability side of the entire sector's balance sheet would lose its force in a broader market context. Still less is it possible to say how the Federal Reserve should then seek to expand its powers ". "reserves" in some form for financial institutions other than depository interwediaries? centralized coordination of capital requirements for all lenders? - in order to re-establish its ability to influence market-wide financial and, ultimately, nonfinancial outcomes. But the direction of the trends shown in figure 1 and 
.41.

especially ligure 2 is clear, and if they continue, then at some point more fundamental questions like these will inevitably move to the forefront. 
Append1x to Section III: The Response of 12 to Open Market Operations

The question at issue is whether an expansionary open market operation.. that is, an increase in nonborrowed reserves - causes M2 to increase or decrease. As a simple 1llustration, consider the following compact, nondynamic model of money, interest rates and nonfinanclal economic activity:

$$
\begin{array}{ll}
\text { (A1) money demand: } & M_{t}-\alpha_{0}+\alpha_{1} Y_{t}+\alpha_{2} r_{S t}-\alpha_{3} r_{L t} \\
\text { (A2) money supply: } & M_{t}-\beta_{0}+\beta_{1} R_{t}+\beta_{2} r_{S t} \\
\text { (A3) term structure: } & r_{L t}-\gamma_{0}+\gamma_{1} r_{S t}+\gamma_{2} \sum_{1} r_{S, t+1}^{e} \\
\text { (A4) aggregate demand: } & Y_{t}=\delta_{0}-\delta_{1} r_{S t}-\delta_{2} r_{L t}
\end{array}
$$

where $M$ is the money stock, $Y$ is nominal income, $R$ is the quantity of nonborrowed reserves, and $r_{S}$ and $r_{L}$ are short-and long-term interest rates, respectively. (In the term structure equation, $r_{S, t+i}^{e}$ Indicates the expectation of short-term interest rates in the future.) All coefficients are assumed to be positive.

If the impact on the short-term interest rate is seen as temporary, the effect on money of a change in nonborrowed reserves in this model is given by

$$
\frac{d M}{d R}-\frac{\beta_{1} Z}{\beta_{2}+Z}
$$


(A6)

$$
2-a_{1} \delta_{1}+\gamma_{1}\left(a_{3}+a_{1} \delta_{2}\right)-a_{2}
$$

If the impact on the short-term rate is seen as permanent, the effect on money is

$$
\frac{\mathrm{dM}}{\mathrm{dR}}=\frac{\beta_{1} \mathrm{Z}^{\star}}{\beta_{2}+\mathrm{Z}^{\star}}
$$

where

$$
2 \star-a_{1} \delta_{2}+\left(\gamma_{1}+\gamma_{2}\right)\left(a_{3}+a_{1} \delta_{2}\right)-a_{2}
$$

In traditional models of money demand, in which money is assumed to bear a fixed (perhaps zero) return and both $r_{S}$ and $r_{L}$ represent competing returns on non-money market assets, $\alpha_{2}$ would have the opposite sign (that is, $\alpha_{2}$ as written would be negative), and so $\frac{d M}{d R}>0$ unambiguously ir, either (AS) or (A7). But for the current situation of $M 2, r_{S}$ is more plausibly the own return. In that case $\frac{\mathrm{dM}}{\mathrm{dR}} \gtrless 0$ as $a_{1} \delta_{1}+\gamma_{1}\left(a_{3}+a_{1} \delta_{2}\right) \gtrless a_{2}$ in the case of the temporary effect on short-term rates (AS, A6) or, analogously, $\frac{d M}{d R} \gtrless 0$ as $a_{1} \delta_{1}+\left(\gamma_{1}+\gamma_{2}\right)\left(a_{3}+\right.$ $\left.a_{1} \delta_{2}\right) \gtrless a_{2}$ in the case of the permanent effect (A7, A8).

This ambiguity prevails even in a short run sufficiently short that open market operations do not yet affect nonfinancial economic activity, so that $Y$ is effectively predetermined with respect to $M$. Replacing (A4) above by

$\left(A 4^{\prime}\right)$ aggregate demand: $\quad Y_{t}=\delta_{0}-\delta_{1} r_{S, t-1}-\delta_{2} r_{L, t \cdot 1}$ simplifies $(A 6)$ and (AB) to 
$\left(A 6^{\prime}\right)$

$\left(\mathrm{A} 8^{\prime}\right)$

$$
\begin{aligned}
& z-\gamma_{1} a_{3}-a_{2} \\
& 2 \star-\left(\gamma_{1}+\gamma_{2}\right) a_{3}-a_{2} .
\end{aligned}
$$

Here $\frac{d M}{d R} \gtrless 0$ as $\gamma_{1} \alpha_{3} \gtrless \alpha_{2}$ or as $\left(\gamma_{1}+\gamma_{2}\right) \alpha_{3} \gtrless \alpha_{2}$, respectively.

Needless to say, moving beyond this simple model, elther by making these

four equations dynamic or by adding further equations, makes the sign condition on $\frac{d M}{d R}$ more complicated rather than simpler. 
This paper was prepared for the Federal Reserve Bank of Kansas City symposium on "Changing Capital Markets: Implications for Monetary Policy," Jackson, Wyoming. August 19-21, 1993. I am grateful to Ben Broadbent for research assistance; to Ernest Furgurson for assistance in identifying the quotation from Clausewitz; to Robert Hall, Donald Kohn, Reiner Konig, Kenneth Kuttner, Allan Meltzer, Richard Porter and David Wilcox for helpful discussions and comments on an earlier draft; and to the G.E. Foundation and the Harvard Program for Financial Research for research support.

1. In 11 ght of the long-standing debate over whether or not money "causes" income, a key feature of such an information variable procedure is that it involves no presumption of causality. All that is necessary is a lead in timing, whether causal or not. See Tobin (1970) for an early and concise discussion of this distinction.

2. See, for example, Simpson (1984). See also the paper by Franklin Edwards in this volume.

3. See Friedman and Kuttner (1992, 1993b) for further deta1ls of the estimation and for the results of alternative specifications.

4. It is useful to recall, however, that the connection between money and prices 1tself rests on "ad hoc" assumptions about the existence of money and its role in the economy, so that the familiar contrast to modeis involving "ad hoc" impediments to Walrasian equilibrium is, in reality, less than usually represented.

5. See, for example, the exchange between Stock and Watson (1989) and Friedman and Kuttner (1993a). Earlier on, see, for example, S1ms (1980) and E1chenbaum and Singleton (1986).

6. See Federal Reserve Bulletin, 64 (July, 1978), 605-610. The basic 1dea, however, was not new then. The Commission on Money and Credit, for example, made a similar proposal in its 1961 report. A key motivation underlying this proposed change was to put non-member institutions of the Federal Reserve System on an equal competitive footing with Federal Reserve members.

7. See, for example, Friedman (1983).

8. The target can of course be an average, perhaps with unequal weights, of other variables. (Divisia aggregates, with optimally selected weights, are an obvious example.) Even a single money growth target is, after all, an average of growth targets for the composite elements of whatever is defined as "money," with welghts on those elements in proportion to their size.

9. McCallum $(1987,1988)$ and others have advocated policy rules centered on the monetary base; but since the base is subject to direct Federal Reserve control (and that is a large part of McCallum's point), under such a 
procedure it would be the instrument of monetary policy, not an intermediate target.

10. Early examples of arguments that bond and/or equity returns in principle affect money demand include Friedman (1956). Meltzer (1963) and Brainard and Tobin (1968). See also Friedman (1977) and Hamburger (1977).

11. Data are from the Flow-of-Funds accounts.

12. See Reid (1993).

13. Allan Greenspan, testimony before the U.S. House of Representatives, Committee on Banking, Housing and Urban Affairs, Subcomittee on Economic Growth and Credit Formation, July 20, 1993, pp. 9-10.

14. See, for example, Laurent (1988), Strongin (1990) and Estrella and Hardouvelis (1991).

15. See again Friedman and Kuttner (1992, 1993b).

16. For example, Friedman and Kuttner (1993b) found that movements in the relative outstanding supplies of commercial paper and Treasury bills exert a highly significant effect on the paper-bill spread, as is to be expected if investors regard paper and bills as imperfect substitutes in their portfolios. Depending upon the estimate of the elasticity of substitution, either a small or a large part of the movement of the paper-bill spread that was not predictive of real output during 1987-90 can be attributed to the fact that the Treasury sharply cut back its issuance of bills beginning in early 1987 and then resumed rapid bill is suance in late 1989.

17. See, for example, Syron (1991).

18. That is sometimes the meaning attached to "discretionary" monetary policy in the economic literature. See, for example, Barro and Gordon (1983).

19. In the absence of reserve requirements, banks would presumably hold reserve balances anyway as a means of clearing transactions. If a private transfer agent provided an alternative clearing system not ultimately resting on reserves transfers, however, the question of the central bank's potential ability to affect banks' behavior via open market operations would again arise. The crucial point is that the central bank maintain a monopoly over some necessary aspect of the banking system's activity.

20. Also see again the paper by Franklin Edward in this volume. For a more fundamental perspective on the role of banks in relation to other intermediaries, and on bank lending in relation to credit provided via open market securities, see Fama $(1980,1985)$ and Bernanke and Gertler (1989). 


\section{References}

Andersen, Leonall C., and Jordan, Jerry L., "Monetary and Fiscal Actions:

A Test of Their Relative Importance in Economic Stabilization." Federal Reserve Bank of St. Louis, Revlew, 50 (November, 1968), 11-24.

Barro, Robert J., and Gordon, David B., "Rules, Discretion, and Reputation In A Model of Monetary Policy." Journal ef Monetary Economics. 12 (July. 1983), 101-121.

Bernanke, Ben S., and Gertler, Mark, "Agency Costs, Net Worth, and Business Fluctuations." American Economis Review, 79 (March, 1989), 14-31.

Brainard, William C., and Tobin, James, "Pitfalls in Financial Model Building." Amerlcan Economic Review, 57 (May, 1968), 99-122.

Brunner, Karl, and Meltzer, Allan H., "Money, Debt, and Economfc Activity." Journal of Polifical Economy, 80 (September-October, 1972), 951-977.

Eichenbaum, Martin, and Singleton, Kenneth J., "Do Equilfbrium Real Business Cycle Theorles Explain Postwar Business Cycles?" Fischer (ed.), NBER Macroeconomics Annual. Cambridge: MIT Press, 1986.

Estrella, Arturo, and Hardouvelis, Gikas A. "The Term Structure as a Predictor of Real Economic Activity." Journal of Finance, 46 (June, 1991), 555-576.

Fama, Eugene F., "Banking In A Theory of Finance." Journal of Monetary Economics, 6 (January, 1980), 39-57.

Fama, Eugene F., "What's Different About Banks?" Journal of Monetary Economics, 15 (January, 1985), 29-39.

Feinman, Joshua N., and Porter, Richard D., "The Continuing Weakness of M2." Mimeo: Federal Reserve Board, 1992.

Feldstein, Martin, and Stock, James $H$. " The Use of A Monetary Aggregate to Target Nominal GDP." Mimeo: National Bureau of Economic Research, 1993.

Friedman, Benfamin M., "The Roles of Money and Credit in Macroeconomic Analysis." Tobin (ed.). Macroeconomics, Prices and Quantities: Essays in Memory of Arthur $M$ Okun. Washington: The Brookings Institution (1983).

Friedman, Benjamin M., and Kuttner, Kenneth N., "Money, Income, Prices and Interest Rates." American Economic Review, 82 (June 1992), 472-492.

Friedman, Benfamin M., and Kuttner, Kenneth N., "Another Look at the Evidence on Money-Income Causality." Journal of Econometrics, 57 (May/June, 1993a). $189-203$. 
Friedman, Benfamin M., and Kuttner, Kenneth N., "Why Does the Paper-Bill Spread Predict Real Economic Activity?" Stock and Watson (eds.). New Research on Business Cycle Indicators and Forecasting. Chicago: University of Chicago Press, 19936 .

Friedman, Milton, "The Quantity Theory of Money -. A Restatement." Friedman (ed.), Studies in the Quantity Theory of Money. Chicago: University of Chicago Press, 1956.

Friedman, Milton, "Time Perspective in the Demand for Money." Scandinavian Journal of Economics, 79 (1977), 397-416.

Friedman, Milton, "Lessons from the 1979-82 Monetary Policy Experiment." Amerlcan Economlc Revlew, 74 (May, 1984), 397-400.

Friedman, Milton, and Schwartz, Anna J., A Monetary History of the United States 1867-1960. Princeton: Princeton University Press, 1963.

Goldfeld, Stephen M., "The Demand for Money Revisited." Brooklngs Papers on Economic Activity (No.3, 1973), 577-638.

Goldfeld, stephen M., "The Case of the Missing Money." Brooklngs Paper on Economic Activity (No. 3, 1976), 683-730.

Hamburger, Michael J., "Behavior of the Money Stock: Is There a Puzzle?" Journal of Monetary Economics, 3 (July, 1977), 265-288.

Judd, John J., and Scadding, John L., "The Search for a Stable Money Demand Function: A Survey of the Post-1973 Literature." Journal of Economic Lterature, 20 (September 1982), 993-1023.

McCallum, Bennett T., "The Case for Rules in the Conduct of Monetary Policy: A Concrete Example." Federal Reserve Bank of Richmond, Economic Review (September/October, 1987), 10-18.

McCallum, Bennett T., "Robustness Properties of a Rule for Monetary Policy." Carnegie-Rochester Conference Serles on Publ1s Policy, 29 (Autumn, 1988), $173-204$.

Meltzer, Allan H., "The Demand for Money: The Evidence from the Time Series." Journal of Political Economy, 71 (June, 1963), 219-246.

Mishkin, Frederic S.. "Information in the Longer-Maturity Term Structure About Future Inflation." Quarterly Journal of Economics, 55 (August, 1990), $815-828$.

Ramey, Valerie, "How Important Is the Credit Channel in the Transmission of Monetary Policy? Carnegie-Rochester Conference Series on Public Policy. 1993, forthcoming.

Reid, Brian, "Senior Financial officer Survey on Retall Mutual Funds." Mimeo: Federal Reserve Board, 1993. 
Simpson. Thomas D., "Changes in the Financial System: Implications for Monetaly Policy." Brooklnes Paners on Economis Activity (No. 1. 1984). 249-265.

Stms. Christopher A., "A Comparison of Interwar and Postwar Puslness Cycles: Mnnetarism Reconsidered." American Eronomis Review. 70 (May, 1980), 250-2147.

Stack, James H. and Watson, Mark W. "Interpreting the Evidence on Money-Income. Causality." Lournal of Econometrics, 40 (January, 1989), 161-182.

Syron. Richard F., "Are We Experiencing a Credit Crunch?" Federal Reserve Bank of Boston, New England Economls Bevisw (July/August, 1991), 3-10.

Tobln. James, "A General Equllibrium Approach to Monetary Theory. " Journal of Monex. Credit and BankIng, 1 (February, 1969), 15-29.

Tohin, James. Money and Income: Post Hoc Ergo Propter Hoc." Quarterly Journal of Economiss, 84 (May. 1970), 301-317.

Tohin, James, Monetary Policy: Rules, Targets, and Shocks." Lournal of Money. Credit and Banking. Is (November, 1983), 506-518. 
</ref_section> 